\title{
Fauna and ecology of the holothurian bed, Llandrindod, Wales, UK (Darriwilian, Middle Ordovician), and the oldest articulated holothurian
}

\author{
Joseph P. Botting and Lucy A. Muir
}

\begin{abstract}
Unlike Cambrian Lagerstätten, Ordovician exceptionally preserved faunas generally differ substantially from each other in taxonomic composition, suggesting a much greater diversity of palaeocommunities during this interval. It is unclear, however, how much of the Ordovician ecological diversity is due to the atypical facies or communities being represented by most of the known exceptional biotas. This paper describes a new Lagerstätte, preserved through high sedimentation rates and early pyritization, from the Middle Ordovician (Darriwilian, Hustedograptus? teretiusculus Biozone) of Wales. A preliminary analysis of the ecology of the fauna, which includes a new methodology for translating preserved abundance of different groups into estimated life abundance, has revealed that an ostensibly trilobite-dominated fauna was dominated instead by brachiopods, reticulosan and protomonaxonid sponges, and palaeoscolecidans, with carpoids and holothurians being nearly as abundant as trilobites. Under normal preservational conditions, this community would appear as a typical Ordovician mudstone fauna, implying that it represents a relatively normal open marine community. The biota does not closely resemble any of the previously described exceptional Ordovician faunas, suggesting that there is a large amount of hidden diversity in communities of this age. Among the exceptional taxa is the earliest known articulated holothurian, Oesolcucumaria eostre gen. et sp. nov., which is a small globular form with partly skeletonised ambulacrae.
\end{abstract}

Joseph P. Botting. State Key Laboratory of Palaeobiology and Stratigraphy, Nanjing Institute of Geology and Palaeontology, Chinese Academy of Science, No. 39 East Beijing Road, Nanjing 210008, China acutipuerilis@yahoo.co.uk

Lucy A. Muir. State Key Laboratory of Palaeobiology and Stratigraphy, Nanjing Institute of Geology and Palaeontology, Chinese Academy of Science, No. 39 East Beijing Road, Nanjing 210008, China lucy@asoldasthehills.org

Keywords: Echinodermata; exceptional preservation; new genus; new species; palaeoecology; pyritisation

PE Article Number: 15.1.9A

Copyright: Palaeontological Association March 2012

Submission: 25 May 2010. Acceptance: 24 November 2011

Botting, Joseph P. and Muir, Lucy A. 2012. Fauna and ecology of the holothurian bed, Llandrindod, Wales, UK (Darriwilian, Middle Ordovician), and the oldest articulated holothuria. Palaeontologia Electronica Vol. 15, Issue 1; 9A,28p; palaeo-electronica.org/content/2012-issue-1-articles/191-welsh-holothurian-bed 


\section{INTRODUCTION}

Palaeocommunity analyses include a variety of approaches, from attempts to recognise repeating assemblages to reconstruction of entire biotas including trophic relationships (e.g., Ziegler et al., 1968; Titus and Cameron, 1976; Wilcox and Lockley, 1981; Williams et al., 1981; Brenchley and Cocks, 1982; Lockley, 1983; Springer and Bambach, 1985; Conway Morris, 1986; Waisfeld and Sánchez, 1996; Álvaro et al., 2007; Caron and Jackson, 2008; Dornbos and Chen, 2008; Holland and Patzkowsky, 2009; Hansen et al., 2010). However, most of these studies have been carried out on standard marine faunas lacking exceptional preservation, and so only include the more easily preservable faunal elements, such as brachiopods, molluscs and trilobites.

Studies on Recent communities have shown that the soft-bodied, less easily preservable component can vary from one-third to over 90 percent of the total number of species (Johnson, 1964); there is a substantial loss of community information during fossilisation. The majority of organisms (both at generic level and as individuals) in the Burgess Shale are ones that would not preserve under normal circumstances (Conway Morris, 1986; Caron and Jackson, 2008); and the same is true of the Chengjiang Lagerstätte (Dornbos and Chen, 2008). Palaeoecologists are well aware of the bias, but are forced to make the assumption that studied faunas have all been equally affected (e.g., Ziegler et al., 1968). The corollary of this assumption is that organisms with hard parts are assumed to be representative of the total community, with the unknown soft-bodied organisms varying little between apparently similar palaeocommunities. It is possible, however, that soft-bodied elements of palaeocommunities could differ dramatically between biotas with similar skeletonised taxa; our ignorance of the less easily preservable organisms may be significantly distorting our view of the history of life. Studies of exceptionally preserved faunas (e.g., Conway Morris, 1986; Caron and Jackson, 2008; Dornbos and Chen, 2008) help mitigate this potential bias. Further studies of other Lagerstätten, particularly those from the post-Cambrian, will enable comparisons between the total faunas of communities yielding similar shelly fossil assemblages.

Even for preservable taxa, there is no doubt that some groups of fossils are better documented than others, and we have argued that this is potentially severely inhibiting the extraction of accurate patterns of diversification (Botting and Muir, 2008).
This could be particularly true of intervals in which large-scale studies are being conducted on the basis of published literature, such as the Great Ordovician Biodiversification Event (e.g., Webby et al., 2004; Servais et al., 2010). For less well-studied groups, monographic effects can radically affect the perceived diversification history of a group (e.g., sponges; Botting and Muir, 2008, figure 3 ).

It is currently unclear to what extent the described, published record accurately reflects the major groups of fossils. For example, Botting and Muir (2008, figure 2) showed that, of the approximately 350 species known to be present in the middle to upper Ordovician of the Builth Inlier, only around $40 \%$ had been described in the literature. The best-known groups were the trilobites, graptolites, brachiopods and sponges, with the majority of the bryozoan, worm, echinoderm and mollusc species unrecorded. Thus an assessment of the diversity and palaeoecology of this area based solely on the published literature would both underestimate the number of species present and misinterpret the palaeocommunities and relative diversity trajectories of different groups.

Detailed studies of total communities are particularly important for elucidating patterns and processes during the Ordovician Radiation, when substantial ecological development was taking place (Harper, 2006; Servais et al., 2010). While some studies of the total fauna of Ordovician communities have been performed (e.g., Walker, 1972; Titus and Cameron, 1976; Brenchley and Cocks, 1982; Frey, 1987; Hansen et al., 2010), trilobitic faunas from muddy facies tend to be divided into only one or two community types, largely defined by the trilobites themselves (e.g., Titus and Cameron, 1976; Brenchley and Cocks, 1982; Hansen et al., 2010). There are as yet insufficient numbers of total-fauna studies of these offshore Ordovician biotas to assess how the communities varied in time and space. This deficiency is especially true for variations within a small region, with a view to establishing a description of community heterogeneity, although some authors have recognised finescale differences between faunules or local populations (e.g., Wilcox and Lockley, 1981; Hansen et al., 2010) and a few have tried to integrate the patterns into a general understanding of a local area (Botting and Muir, 2008).

Recent years have seen the discovery of several new exceptionally preserved Ordovician biotas (Aldridge et al., 2001; Liu et al., 2006; Young et al., 2007; Van Roy et al., 2010; Botting et al., 2011) 


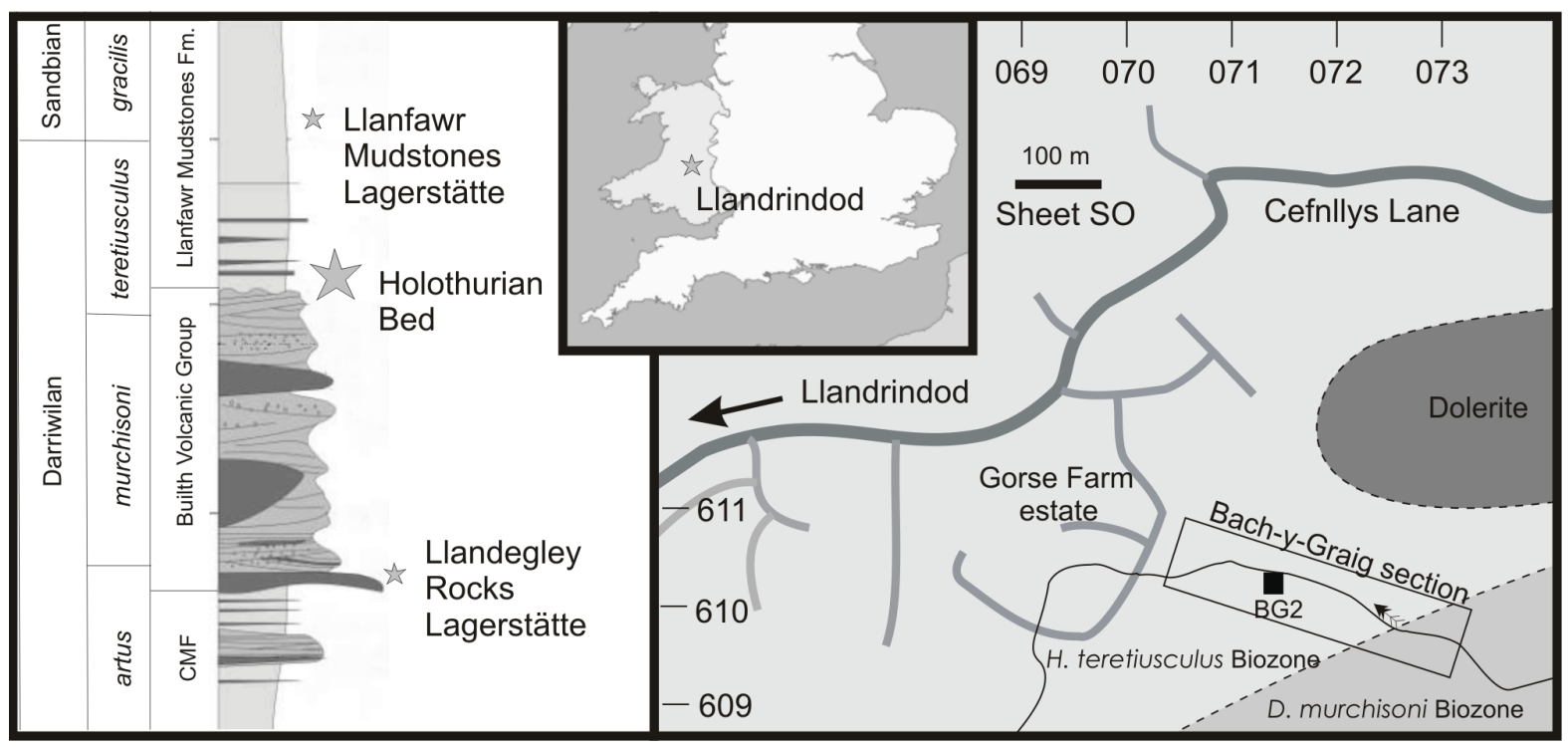

FIGURE 1. Stratigraphic column and map showing the location of the Holothurian Bed locality near Llandrindod, Powys, Wales (inset map shows location within southern UK). Llanfawr Mudstones Lagerstätte refers to Botting et al. (2011), and the Llandegley Rocks Lagerstätte was described by Botting (2005). CMF: Camnant Mudstones Formation. The boundary between the Didymograptus murchisonii and Hustedograptus? teretiusculus biozones is not well constrained, except in the stream itself, where it is somewhat faulted (Sheldon 1987b).

and global collaboration on biodiversification patterns (e.g., Servais et al., 2010). Unlike the Cambrian Burgess Shale-type deposits, however, Ordovician Lagerstätten appear to differ dramatically from each other in taxonomic composition. This variation may be partly due to the different environments and taphonomic modes represented, and partly to genuine ecological disparity, but current data are insufficient to decide the importance of each factor. Additional exceptionally preserved faunas with a variety of taphonomic styles will reveal whether these communities really did differ in fundamental ways (e.g., dominance of different groups or different trophic guilds; organism interaction intensity). In particular, multiple exceptionally preserved biotas are needed from the trilobitic biofacies, in mudstones and siltstones deposited in open marine settings, in order to compare directly with the ecology of the Burgess Shale-type faunas of the Cambrian.

In this paper we describe an exceptionally preserved fauna from an open marine siltstone, and attempt an ecological interpretation of the community. Although the Holothurian Bed is not equivalent in importance to the few well-known Ordovician Lagerstätten (Aldridge et al., 2001; Liu et al., 2006; Young et al., 2007; Van Roy et al., 2010), it is more diverse than some (e.g., Beecher's Trilobite Bed; Cisne, 1973) and preserves some elements of the community that are rarely encountered in other Ordovician biotas, such as palaeoscolecidans and holothurians. It is also unusual for an Ordovician site of exceptional preservation in representing a relatively deep, open marine community, albeit with unusual characteristics due to the influence of volcanic ash. Although major Lagerstätten are the most informative deposits for studying local palaeoecology, more limited biotas can also reveal new information about these ecosystems, provided that they preserve some components that are not normally represented. A range of faunas similar to the Holothurian Bed, particularly from one area, would combine to be as informative as a single, high-diversity Lagerstätte. Although the total diversity and the extent of soft tissue preservation are limited, this fauna yields new insights into an otherwise familiar Ordovician community, and provides new information for understanding the development of Ordovician ecosystems.

\section{LOCALITY}

The Holothurian Bed (introduced in this paper) is a short (approximately $50 \mathrm{~cm}$ ) interval of siltstone immediately overlying a tuff bed within the upper part of the extensive Bach-y-Graig section, near Llandrindod, central Wales (Figures 1, 2), grid reference SO 07106102. It falls within the lower part of the Llanfawr Mudstones Formation, in the basal part of the Hustedograptus? teretiusculus Biozone (Llandeilian, Darriwilian). The formation is 


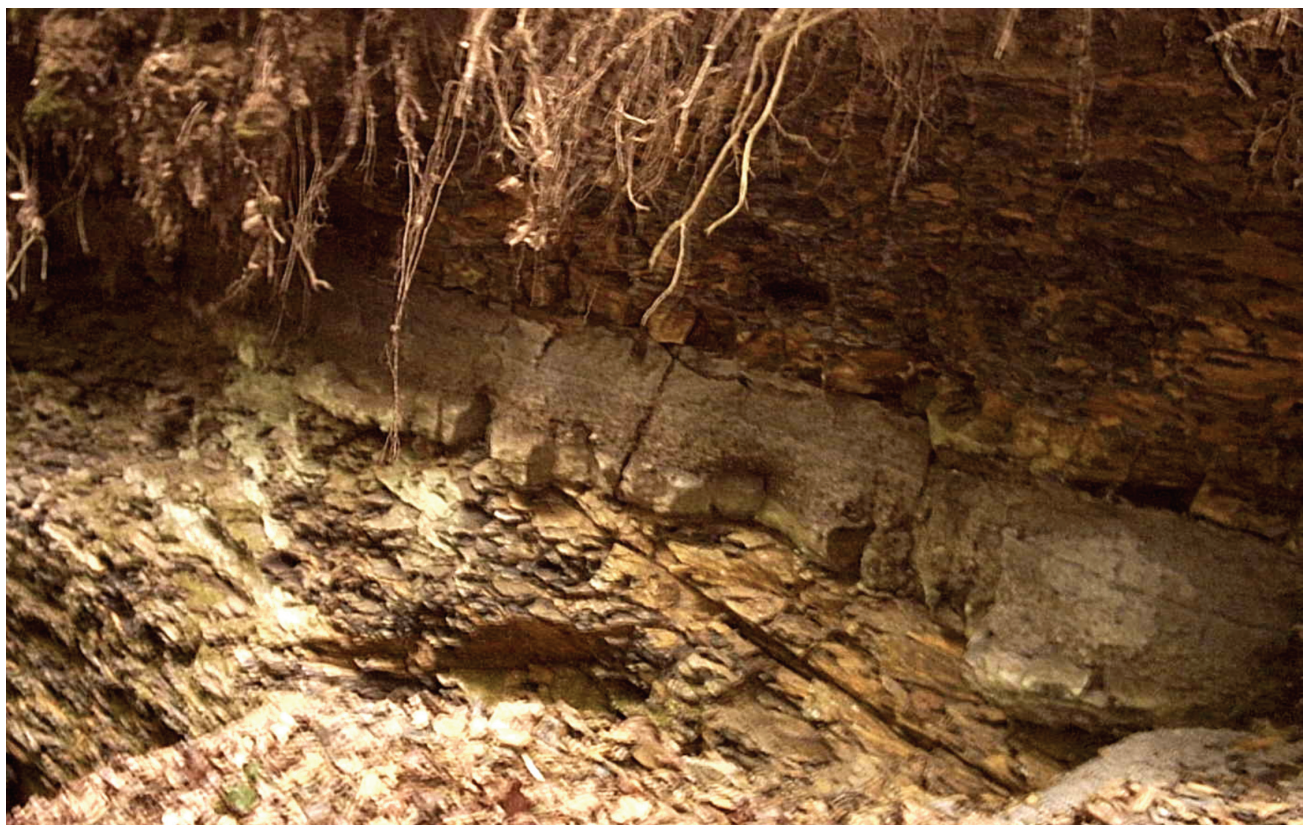

FIGURE 2. Outcrop of the Holothurian Bed, in the upper part of the section; the interval described here overlies a thick tuff bed visible in the upper half of the view. Beds underlying the tuff are blue-grey mudstones with similar fauna to the non-exceptional components found above it. The tuff bed is $27 \mathrm{~cm}$ thick.

well known for well-preserved trilobite (Hughes, 1969, 1971, 1979; Owens, 1981, 2002; Sheldon, 1987a) and graptolite faunas (Elles, 1940; Hughes, 1989), with exceptional faunal elements including diverse sponge assemblages (Botting, 2004). Recently, the upper parts of the formation have been shown to yield locally abundant soft-tissue preservation as pyrite in black mudstone (the Llanfawr Mudstones Lagerstätte of Llanfawr Quarry, Llandrindod, Botting and Muir, 2005; Botting et al., 2011), different in lithology and fauna from the Holothurian Bed. Both Llanfawr Quarry-like and Holothurian Bed-like rocks occur widely in the area, which implies that soft-tissue preservation may be widespread within the Llanfawr Mudstones Formation. Both the exceptional localities so far known had previously been studied in detail, but their exceptional faunas had been overlooked, perhaps due to surface degradation of the pyritised fossils through weathering.

The Bach-y-Graig stream section shows intermittent exposures through approximately $200 \mathrm{~m}$ of the latest Didymograptus murchisoni and earliest $H$. ? teretiusculus biozones, in a wooded stream valley on the eastern edge of Llandrindod (Elles, 1940; Sheldon, 1987b). It is adjacent to a housing estate, and although the section is in need of clearance, some outcrops are easily accessible. The lithology through the sequence is predominantly argillaceous, but ranges from graptolitic black mud- stone through siltstones and flaggy fine sandstones. The section is punctuated by numerous tuff beds, some of them over $1 \mathrm{~m}$ thick, and thousands of fine ashy laminae interspersed in the sequence. Exposure is generally poor, with a few small crags on the banks of the stream, and most outcrops are heavily weathered.

The Holothurian Bed is located in a major exposure (locality BG2 of Botting, 2000), approximately $40 \mathrm{~m}$ from the point at which the stream emerges from the trees, on the left bank. The exposure is deeply weathered, and consists of $3 \mathrm{~m}$ of dark to pale grey, locally ashy shale with a $27 \mathrm{~cm}$ thick tuff bed in the upper part, and approximately $50 \mathrm{~cm}$ of shale exposed above it (Figure 2). The tuff is tripartite, with a basal fine, sandy tuff, a normally graded, coarse to fine sand unit in the centre, and a fine, nearly flinty cemented ash at the top. The upper margin of the tuff shows some evidence of reworking, occasional small burrows and indistinct ripple lamination. There are dispersed fine ashy laminae both above and below the tuff. The holothurians and associated fauna occur through the approximately $50 \mathrm{~cm}$ of rock above this tuff unit, and are concentrated between 10 and $30 \mathrm{~cm}$ above its upper surface.

The rock at this level is deeply weathered, pale grey silt and fine sand, with numerous thin white ashy laminae, some of them gritty. Weathered surfaces are strongly iron-stained. There is lit- 
tle fresh pyrite visible in hand specimen, but occasional bedding planes show pyritised spiculitic layers and some trilobite fragments retain pyritic coatings. Deep excavation for fresh material is hampered by overhanging soil and tree cover on the steep slope, and tree roots in the soil, but we hope to arrange larger excavations in future.

\section{ENVIRONMENTAL INTERPRETATION AND TAPHONOMY}

The Bach-y-Graig stream section has previously yielded the majority of the agnostids and cyclopygids (Owens, 2002) recorded from the Builth Inlier, and possibly represents the deepest water depth experienced in the exposed sequence. Based on the presence of cyclopygids and agnostids, which are rare or absent elsewhere in the Builth Inlier sequence and which are thought to indicate shelf-edge conditions, the water depth was perhaps 300-400 m (Fortey and Owens, 1987). The geological history of the Builth Inlier relates to the formation, subsidence and erosion of a volcanic island complex (Jones and Pugh, 1949; Botting and Muir, 2008); high sedimentation rates would have resulted from steep, unstable slopes during the subsidence and erosion. An obvious but perhaps over-simplistic interpretation is that the fauna was enveloped by a near-continuous series of minor slumps or turbidity flows, during a benthic bloom that resulted from the volcanic ash deposition (Botting, 2000, 2002). However, several features of the fauna indicate that the bed does not represent a standard obrution deposit. Although there are occasional specimens recorded from elsewhere in the Bach-y-Graig section that may suggest a shallower-water origin (large, Pyritonema-like sponge spicules, and rare orthid brachiopods), the Holothurian Bed fauna is consistent with strictly limited post-mortem transport. In particular, the presence of articulated sponges and trilobite moults, and evidence for ecological interactions, must represent effectively in situ burial, rendering any sort of transport highly unlikely. This requires burial by episodically elevated rates of fallout sedimentation rather than discrete flows, or at least of flows which were sufficiently slow and diffuse as to not disturb delicate trilobite moults or ostracodes feeding on organic detritus. Settling of reworked fine sediment clouds from agitation of nearshore water, and also (in the case of some of the fine ashy laminae) direct ashfall, may be a more accurate scenario. Although sedimentary structures have been largely destroyed by weathering, an interpretation of depo- sition mainly by suspension fallout is supported by locally preserved fine laminations, often differing in colour and hence probably ash content. No sponges are preserved vertically (as would be expected if incorporated into a flow), but some show weak evidence of current alignment; this suggests some degree of local, gentle transport, at least at some horizons, but no example of sponges damaged by violent transport have been found. Suspended sediment fallout from diffuse, slowmoving turbid flows may also provide a kill mechanism for echinoderms, trilobites and palaeoscolecidans, as these creatures may be expected to have been capable of escaping from abrupt burial by only a few millimetres (pre-compaction) of sediment.

Holothurian Bed specimens show a wide range of preservational styles in terms of mineralogy. Trilobites are typically slightly compressed moulds (e.g., Figure 3.8), although sometimes there are traces of remnant calcite or secondary silica (Figure 3.4), and some carapaces have been replaced by pyrite, now mostly weathered (Figure 3.7). Other originally calcareous organisms (bivalves, gastropods, ostracodes and echinoderms) show a similar mouldic preservation with irregular crystal infilling (either silica or calcite) (e.g., Figure 4.1), but are generally uncompressed; iron staining after partial pyrite replacement is common in carpoids (Figure 5.1). Graptolites are thin, reflective films that appear carbonaceous but may have some element of clay mineral replacement (Figure 6.1, 6.2). Obolid brachiopods and conodonts are preserved with phosphate largely dissolved, and often effectively mouldic with a brown organic layer (Figure 6.4), although the largest lingulid shells retain a hard, black, reflective substance that is presumed to be partly phosphatic. Silica is found in large, isolated sponge spicules, but rarely in the spicules of intact sponge bodies, and often occurs secondarily as irregular growths in mouldic fossils of other groups.

The most common mineral preserving exceptional fossil specimens is weathered iron oxide, probably principally after pyrite. Pyrite grains and framboids occur abundantly in the matrix, and are occasionally found unweathered on laminae of concentrated sponge spicules or other organic detritus. In articulated sponges (Figure 4.2) and holothurians, the body is marked by an iron-stained film with spicules or sclerites impressed into the surface. In some fossils, especially sponges, the iron-stained material forms a thick layer that obscures the skeletal structure, representing either 


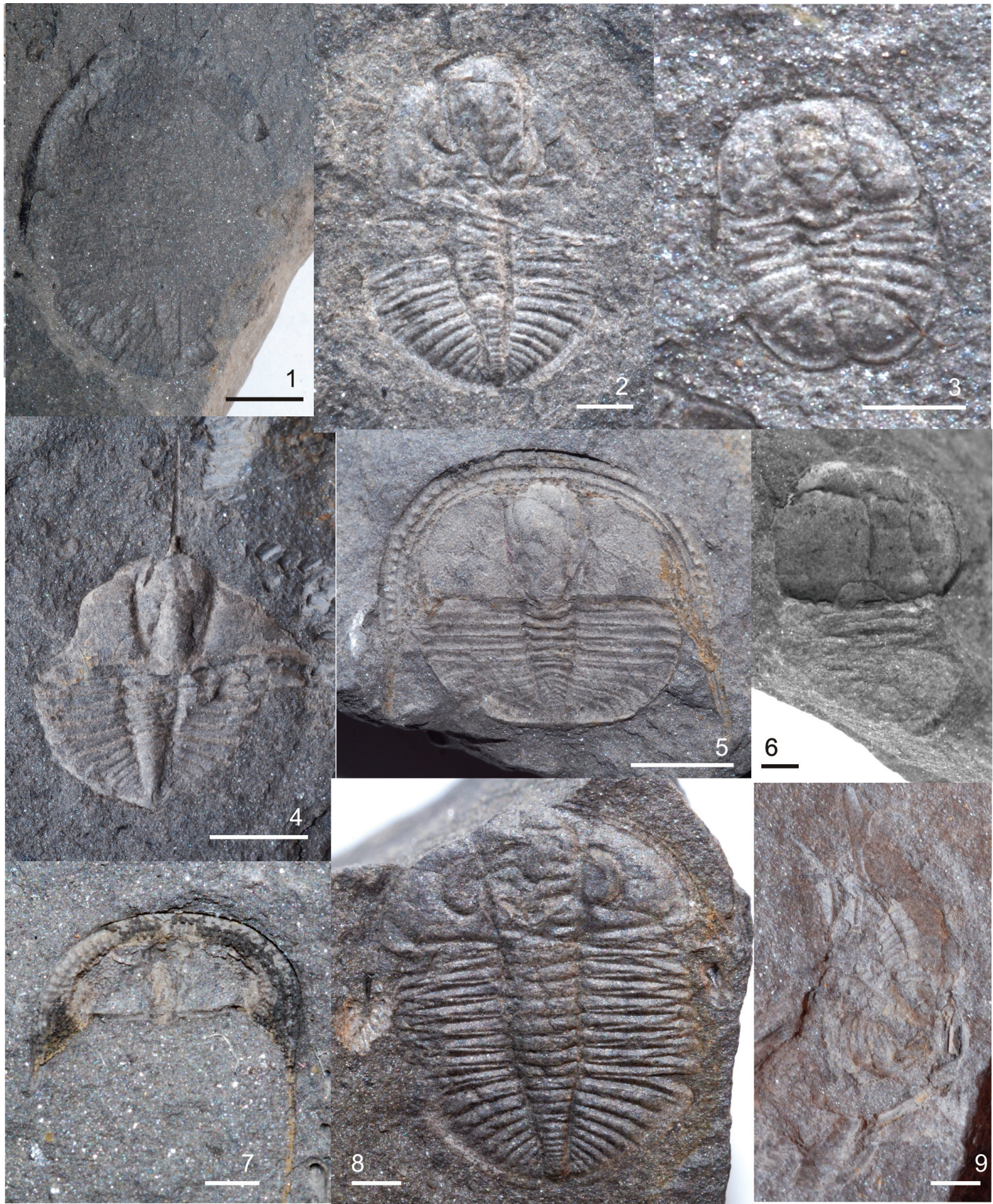

FIGURE 3. Trilobites from the Holothurian Bed, Bach-y-Graig. 1, Ogygiocarella? sp., recently moulted, wrinkled specimen NMW2011.2G.7, scale bar equals 5 mm. 2,Ogyginus corndensis, articulated moult NMW2011.2G.6, scale bar equals $1 \mathrm{~mm}$. 3, Ogyginus corndensis meraspis, NMW2011.2G.31, scale bar equals $1 \mathrm{~mm}$; 4, Cnemidopyge parva NMW2011.2G.28, scale bar equals $5 \mathrm{~mm}$; 5, Protolloydolithus reticulatus NMW2011.2G.4, scale bar 5mm; 6, Microparia sp. NMW2011.2G.20, scale bar equals $1 \mathrm{~mm} ; 7$, Protolloydolithus reticulatus showing replacement of skeleton by pyrite NMW2011.2G.30, scale bar $1 \mathrm{~mm}$; 8, Ogyginus corndensis NMW2011.2G.15, scale bar equals $1 \mathrm{~mm}$; 9 , Cluster of trilobite fragments NMW2011.2G.27, scale bar equals $1 \mathrm{~mm}$. 


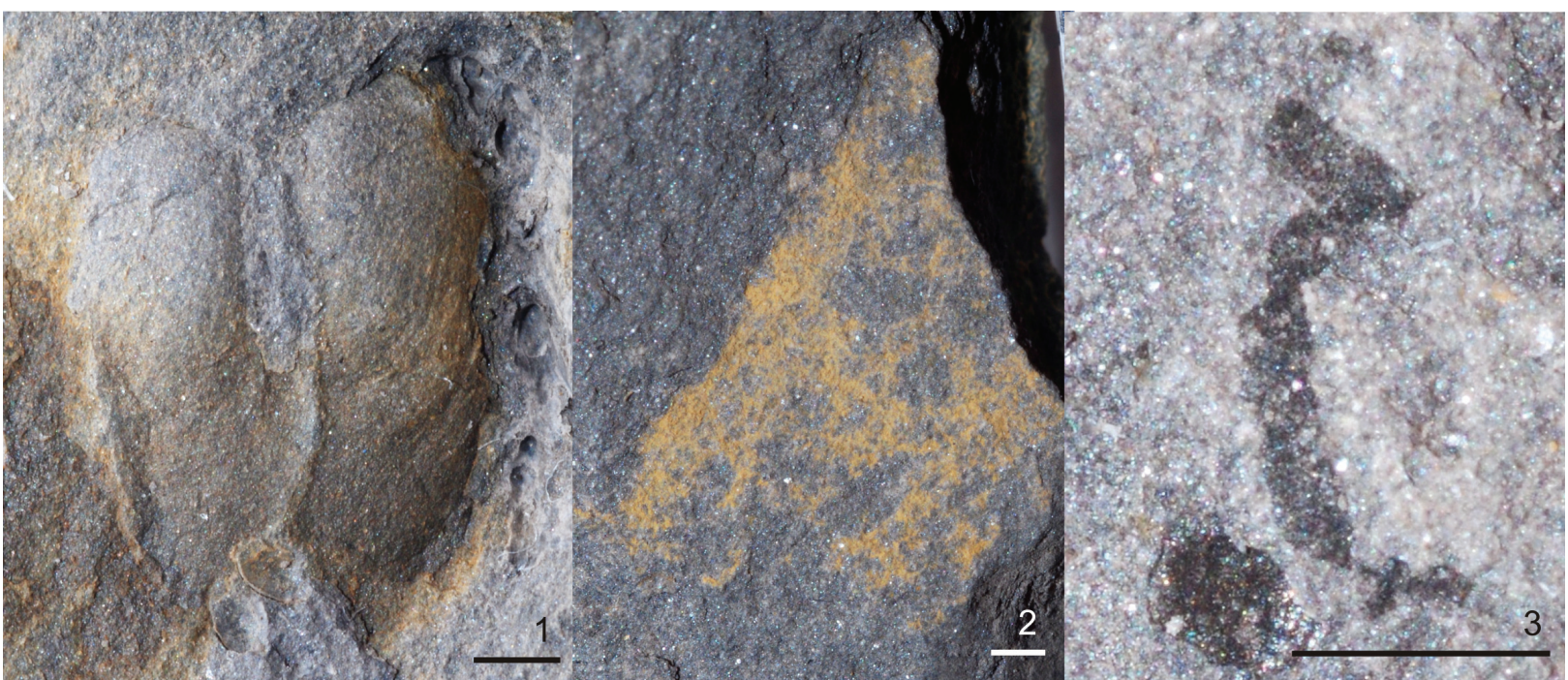

FIGURE 4. Representative fossils from the Holothurian Bed, Bach-y-Graig. 1, undescribed bivalve NMW2011.2G.11, scale bar equals $1 \mathrm{~mm}$; 2 , fragment of undescribed hexactinellid sponge, showing typical preservation due to weathered pyrite, NMW2011.2G.14, scale bar equals $1 \mathrm{~mm}$; 3 , undescribed palaeoscolecidan worm with dark carbonaceous and/or phosphatic preservation of plates NMW2011.2G.26, scale bar equals $1 \mathrm{~mm}$.

more substantial soft-tissue preservation, or a thick, secondary pyritic overgrowth.

Anecdotally, the colour of the oxidised iron minerals appears different between taxa, and in some cases even between different species of sponge. This colour varies between bright orange, a dull reddish-brown and dark brown to black. Such a taxonomic constraint on iron mineral preservation is not to our knowledge understood, and although it is not absolute within the samples, this feature warrants further investigation. In the event of excavations yielding unweathered material, detailed chemical analyses of the samples may be instructive.

\section{Effects of the Volcanic Ash on Major Faunal Components}

Botting (2000) included the interval surrounding the tuff (and two other intervals in the Bach-yGraig section) as part of a study of the effects of ashfall on ecology. In that work, fine-scale sampling of the fauna through successive $2 \mathrm{~cm}$ thick intervals was carried out, and abundance calculated based on a normalised sample size of $100 \mathrm{~g}$. Specimens of the small obolid brachiopod Apatobolus? micula, graptolites and ostracodes were counted. He found that abundance of $A$ ? micula varied from near zero immediately after ash deposition, through a smooth increase to a maximum of over 80 individuals per $100 \mathrm{~g}$; thin concentration horizons yielded up to 400 individuals per $100 \mathrm{~g}$. These results were consistent with those in other samples. The abundance of $A$ ? micula followed a bimodal curve, interrupted in this section by further ash deposition near the beginning of the second peak. This reflects successive (pseudo-)planktic and benthic bloom events, probably related to overturning of a partially stratified water mass (for full discussion see Botting 1999, 2000, 2002). The critical point for the purposes of this discussion is that the fauna in the sequence does not represent an equilibrium community, but reflects to some extent the faunal dynamics through a colonisation and bloom interval. The restriction of some taxa to, or concentration in, certain levels must be understood partly through taphonomic considerations, but also partly in light of this ecological element.

\section{MATERIALS AND METHODS}

This study is based on extensive collecting by the authors over a number of years. Specimens have been deposited in the University of Birmingham, the Sedgwick Museum, Cambridge, the Natural History Museum, London (NHM), the National Museum of Wales, Cardiff (NMW) and the Radnorshire Museum, Llandrindod. Figured specimens are in the NHM and NMW. Species-abundance curves (Figure 7) were drawn on two separate occasions, each taking two days of fieldwork for three or four people; bulk samples were removed from the outcrop and split as finely as was practical in the field, in order to record every specimen, except the super-abundant obolid brachiopod Apatobolus? micula. This species was excluded 


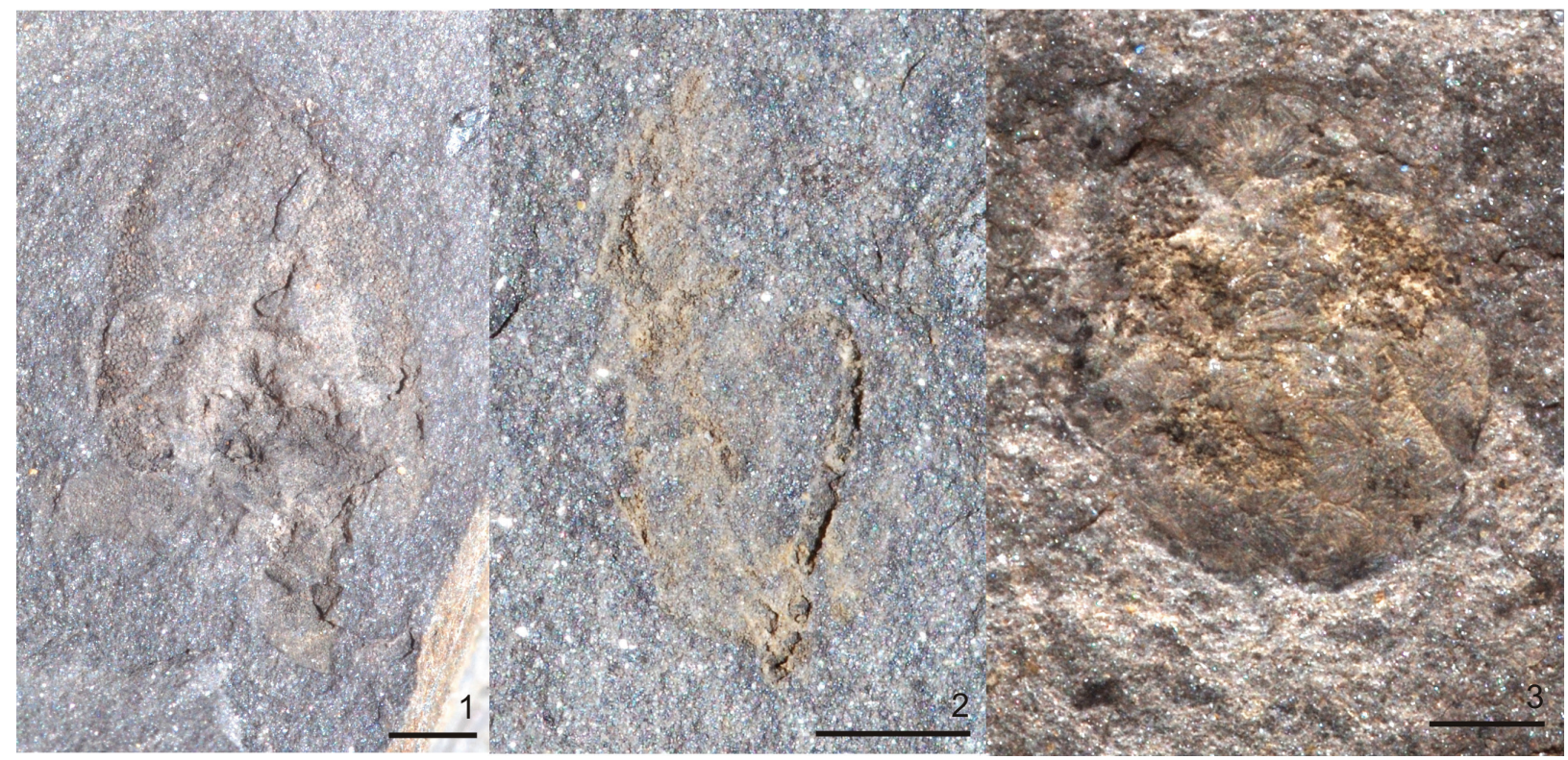

FIGURE 5. Echinoderms from the Holothurian Bed, Bach-y-Graig. 1, articulated mitrate (Anatifopsis?) NMW2011.2G.12, scale bar equals $1 \mathrm{~mm}$; 2, undetermined carpoid(?) echinoderm NMW2011.2G.25, scale bar equals $1 \mathrm{~mm}$; 3 , undetermined "cystoid" with arachnoid plates, NMW2011.2G.34, scale bar equals $1 \mathrm{~mm}$. See also Figure 9 for holothurian specimens.

because it is at least an order of magnitude more abundant than any other taxon; in some laminae there are several hundred valves per $100 \mathrm{~g}$ of rock (Botting, 2000). Although it would be possible to count these specimens, it is also unnecessary, impractical and limits the collecting of rarer taxa in the time available.

\section{Estimation of Preserved and Life Abundance}

Aside from major Lagerstätten in which the preserved assemblage in a particular bed can sometimes accurately represent the instantaneous life community (Conway Morris, 1986), attempts to reconstruct palaeontological assemblages as life communities (e.g., Wiedman 1985) are fraught with uncertainties. There is as yet little consensus on the details of the corrections to be used when converting between palaeontological assemblages and life communities, which must in general be specific to the deposit under study. These can be as simple as the number of arthropod moults to take into account when calculating relative abundances, through to interpretation of the taphonomic biases inherent in different degrees of sclerotisation and the effects of magnesium content in calcium carbonate skeletons on dissolution. Although a standardised system would be ideal, the correction factors required will vary considerably between localities due to differing taphonomy.
Relative proportions of different fossil species depend on not only their life abundance, but also their life history (particularly growth mode) and taphonomy. Even with organisms with hard parts, simply counting preserved abundance does not give life abundance, or even a relative measure of it. Organisms that moult (trilobites, ostracodes and palaeoscolecids for this locality) will produce more than one set of preservable hard parts during their lifetimes, whereas multi-element skeletons are prone to disarticulation, and different biominerals have different preservation potentials.

To try to account for these biases, we have attempted to estimate relative abundance during life by using correction factors on preserved abundances (discussed in detail below). Due to the nature of collecting over numerous field seasons, the values are approximate only; this is not a rigorous statistical analysis, but rather an attempt to uncover the basic relative proportions of the groups present and present a realistic outline of the palaeocommunity. We are here considering the whole bed as a single community, even though this will involve a certain amount of time-averaging. Botting (2000) did consider this to a certain extent, but those results were too limited to record changes in rarer taxa, and mitrates were not recognised in that study. We hope to conduct a rigorous analysis based on these methods in the future, dependent on the opportunity to make a large- 


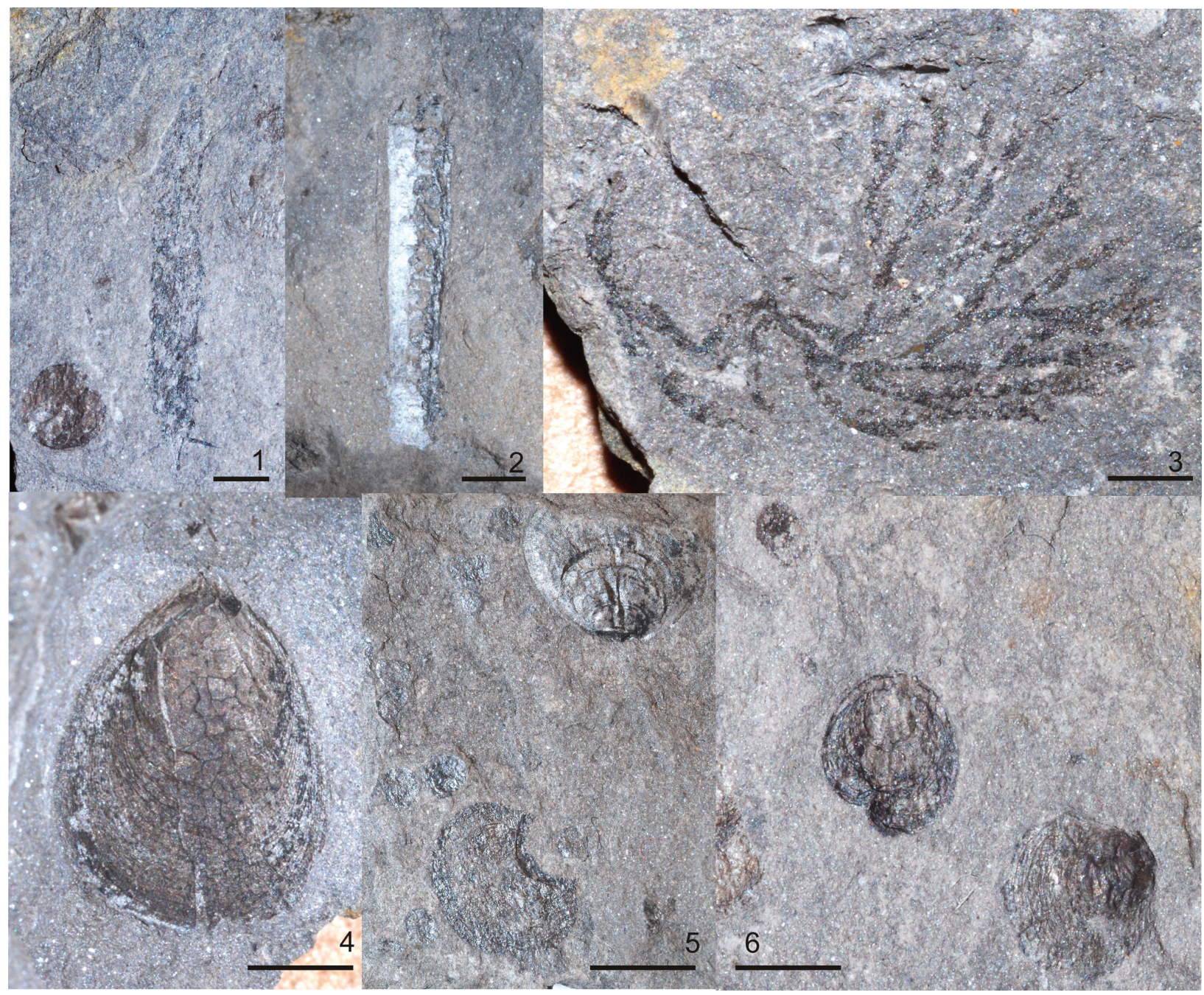

FIGURE 6. Graptolites and brachiopods from the Holothurian Bed, Bach-y-Graig. 1, Cryptograptus tricornis showing typical preservation for graptolites NMW2011.2G.2, scale bar $2 \mathrm{~mm} ; 2$, Hustedograptus? teretiusculus with combination of carbonaceous and probably aluminosilicate preservation NMW2011.2G.3, scale bar equals $2 \mathrm{~mm}$; 3, Dendrograptus sp. NMW2011.2G.1, scale bar equals 5 mm; 4, Palaeoglossa attenuata NMW2011.2G.19, scale bar equals $2 \mathrm{~mm} ; 5$, Schizotreta sp. encrusting a weakly preserved substrate, NMW2011.2G.9, scale bar equals $5 \mathrm{~mm} ; 6$, Small cluster of Apatobolus? micula (see also Figure 8.5) NMW2011.2G.37, scale bar equals $2 \mathrm{~mm}$.

scale excavation and collect samples from several intervals within the unit, including consideration of individual bedding surfaces.

We have taken the mitrate Anatifopsis? sp. as our baseline organism, because it didn't moult, it had robust hard parts (the two large plates of which have a high preservation potential), and we have significant numbers of both articulated and disarticulated specimens. Due to the fragility of carpoid soft tissues and the lack of articulation of the skeleton, any specimen preserved in articulated or semiarticulated condition is taken to have been buried alive or very shortly after death. Isolated large plates are assumed to have been on the sea floor for some significant time and to have been subject to complete decay or scavenging. Each individual mitrate possessed two large plates, so we have divided the total number of isolated large plates by two to obtain the number of disarticulated individuals these plates represent. We have seen seven articulated specimens, and isolated large plates representing approximately 140 disarticulated individuals, providing a ratio of 20 disarticulated specimens to one articulated one. This implies that for mitrates, roughly 20 times as many individuals were subject to sea-floor exposure and disarticulation as were buried rapidly.

This figure can be tentatively applied, sometimes in modified form, to other organisms that would not normally be preserved without abrupt 


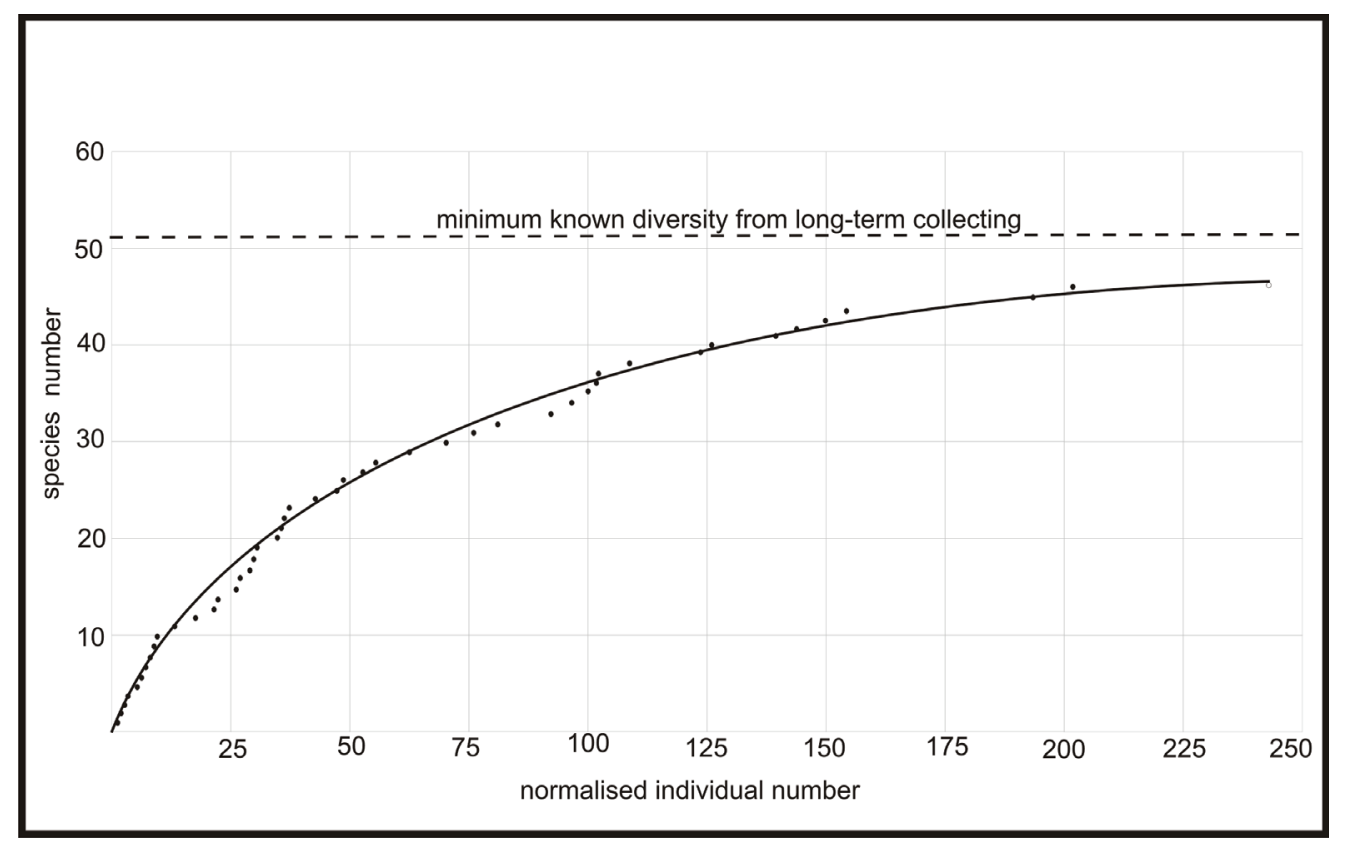

FIGURE 7. Species-abundance curve obtained from in situ sampling exercise over two days, excluding Apatobolus? micula. Note that the curve appears to level out at approximately 48 specimens, but we are aware of a minimum diversity of 52 species at the site, and the true diversity will be substantially higher.

burial, to estimate relative values for life abundance. In anoxic settings, application of such correction factors would be more problematic, as skeletal disarticulation would be dependent only on decay rates, which is likely to vary considerably between groups. In the Holothurian Bed, a diverse and abundant benthos included numerous presumed scavengers (particularly trilobites and ostracodes), which would have broken down carcasses much more rapidly. As a result, articulated remains can be considered to represent abrupt, or at least (approximately) equally rapid burial for all taxa prone to rapid post-mortem disarticulation. The correction factor must be modified when there are additional considerations involved that affect the observed totals, such as growth by moulting; these factors are discussed for each group below. The correction factor is applied by multiplying the observed abundance of complete organisms (c) by the appropriate correction factor $\left(C_{i}\right)$, and adding this to the observed number (c), such that:

$$
\text { Estimated life abundance } \mathrm{E}_{i}=\mathrm{CC}_{i}+\mathrm{c}
$$

Multiplying $\mathrm{c}_{\mathrm{c}}$ by $\mathrm{C}_{i}$ gives the number of individuals that are not preserved intact; it is necessary to add $\mathrm{c}$ in order to estimate the total life abundance.

This method relies on several assumptions and is not appropriate for all biotas; most of these requirements are satisfied in typical offshore mudstone deposits.

1. The fauna must be time-averaged over an interval that is significantly longer than the organisms' life spans. For instantaneous obrution deposits, the measures described here are unnecessary.

2. Exceptionally preserved, complete specimens were killed at the time of burial. In deposits with abundant benthos this assumption is probably safe, as scavenging would break up recently dead organisms.

3. Biostratinomic and taphonomic loss has been insignificant for the baseline organism; the correction factor calculated from this species can then be applied to organisms that have suffered loss. The method therefore cannot normally be applied to shallow-water communities where wave action and destruction by algal boring are significant.

4. Organisms included in the analysis should be epifaunal, as infauna may remain articulated for anomalously long periods after death.

The critical requirement for application of this technique is the existence of an appropriate baseline organism. Anatifopsis is ideal in possessing a complex, easily disarticulated skeleton with a small number of distinctive plates, and in not producing 
moults. Certain other echinoderms (other carpoids, certain crinoids with distinctive radial or other plates) may also fulfil these requirements. Other organisms that may serve as baseline fossils when articulated examples are present are hyoliths, machaeridians and conodonts. Epibenthic brachiopods may also be appropriate in at some cases, although rhynchonelliforms with articulating hinges would be more resistant to disarticulation; epibenthic lingulates may, however, provide a reasonable correction factor. Trilobites are difficult to employ due to complications over moulting, and the ligament of bivalve molluscs retains articulation long after death. To assess the utility of a group, comparison can be made between correction factors derived from different taxa in the same deposit; in this case, the higher ratio for disarticulated to articulated remains should be used.

\section{Application of the Correction Factor to Different Groups}

The correction factor derived from Anatifopsis can be applied, with modification where appropriate, to other groups in the Holothurian Bed. For sponges, disarticulated specimens are usually not visible, and even when they are, no estimate of abundance can be made from isolated spicules. Therefore, the only sponge specimens we see are those buried before or very shortly after death, and the standard correction factor can be applied directly. A similar correction is appropriate for holothurians (an underestimate due to the relative lability of soft tissues) and other groups, allowing estimates of relative life abundance across the entire community. For palaeoscolecids, we have assumed that all specimens preserved as thick weathered iron minerals were alive at the time of burial. Only two apparent moult fragments have been collected, reflecting the rapid disarticulation of moulted scleritomes into extremely small plates. This ratio implies that at any moment, there were more live specimens than moults on the sea floor.

For trilobites, there are additional considerations, complicated by the fact that numbers for the abundant isolated sclerites are not available. Counting only intact individuals (non-moults) and using the full correction factor derived from mitrates removes the problem of exuviae biasing estimates upwards, but leads to errors if a complete individual remained intact on the sea floor for longer after death than did carpoids. As trilobite skeletons are connected by relatively recalcitrant organic tissues (which may also have been less attractive to scavengers than soft tissues would have been), the correction factor should be considered to give a maximum estimate. Alternatively, articulated moults are much more common in the deposit, and will potentially provide a more accurate value; the problem is estimating the number of moults to divide the correction factor by. Trilobites are present in the samples from early instar juveniles to relatively large adults, and we have conservatively selected a low estimate of five moults; a fully developed adult would have had more instars (Sheldon, 1988), but many of the non-moult specimens we have seen are relatively early growth stages that did not reach full maturity, and a certain degree of juvenile mortality is inevitable. A higher number of moults per individual would further reduce the calculated trilobite abundance, so that our estimate for trilobite abundance should be taken as a maximum value.

Ostracode early instars are presumed to have been too small to be visible in the field (and perhaps not preserved), and a correction factor divided by four (the precise value is arbitrary) to allow for moulting has been used here. This is, if anything, an overestimate of the number of moult stages that would have been practically visible, and the resulting estimate of ostracode abundance should therefore be regarded as a minimum.

In future excavations with rigorous data collection, it should be possible to measure ostracodes and articulated trilobite moults, so that clustering of the points can reveal the exact number of instars represented in the collected or counted samples. This would remove the uncertainty, and result in more accurate assessment of their life abundances.

Non-ecdysozoan organisms with mineralised skeletons, such as molluscs and brachiopods, are easier to assess. Numbers of valves are divided by two for bivalved organisms; although it is possible that transport could bias relative valve abundance, in some species (especially phosphatic brachiopods) it is very difficult to distinguish brachial from pedicle valves. Single-shelled lophotrochozoans or cnidarians are counted as individuals, and fragments are not counted unless they include the proximal end. The same applies to graptolites, where a colony is treated as an individual; fragments are excluded except where they include the proximal end. 


\section{FAUNA}

\section{Diversity and Composition}

Like the rest of the Bach-y-Graig section, the fauna is traditionally regarded as principally a trilobite-dominated assemblage. This, however, only reflects the most obvious faunal component, or, more accurately, the one that most visitors to the locality are likely to collect. As discussed below, taken purely in terms of life abundance of individuals, it is an obolid brachiopod-sponge-palaeoscolecid community. Trilobites are frequent, but a relatively minor component of the fauna, and several other groups are also present in significant numbers. The groups are treated individually below. A list of the total fauna recorded to date from the Holothurian Bed is presented in Table 1.

\section{Trilobites (Figure 3)}

The trilobite fauna is reasonably diverse and includes some rare taxa. The most abundant species are the raphiophorid Cnemidopyge parva (Figure 3.4), the asaphids Ogyginus corndensis (Figure 3.2, 3.3, 3.8) and Oygiacarella debuchii, the trinucleid Protolloydolithus reticulatus (Figure $3.5,3.7)$ and the proetoid Rorringtonia kennedyi. In addition to these, there are agnostids (Geragnostus mccoyii), nileids (Barrandia sp.), cyclopygids (including Microparia lusca, and perhaps other species of Microparia and other cyclopygids, Figure 3.6), calymenids (Platycalymene tasgarensis simulata) and an undetermined odontopleurid.

A peculiarity of the trilobites from the interval is an unusually high abundance of early growth stages, as recognised by small size combined with a sub-adult number of thoracic ribs. A preliminary estimate from field surveys suggests that at least two-thirds of articulated scleritomes are sub-adult. Clusters of juvenile trilobites, usually of different species, are not uncommon at this locality (e.g., Figure 3.9); these are discussed further in the ecology section below.

\section{Molluscs (Figure 4.1)}

Represented only by rare fossils, there are nonetheless at least three or four species of mollusc, including at least one species each of orthoconic nautiloid, gastropod and bivalve. None have yielded sufficient material for a full description. The nautiloids occur sporadically through the bed, but the benthic molluscs have been found within relatively dense assemblages of benthos. In some cases, the small, pleurotomariid-like gastropods are associated with ostracodes and trilobite clus- ters, suggesting scavenging or grazing behaviour on unpreserved organic matter.

\section{Sponges (Figure 4.2)}

Reticulosan hexactinellid sponges and protomonaxonids are in most deposits extremely rare as fossils due to the fragility of their skeletal mesh, although they can be preserved in abundance under the right conditions. At least 10 species of sponge are present in the Holothurian Bed interval, concentrated at the same level as the holothurians, but also present through a greater thickness. Some specimens show exquisite preservation, including a clear oscular margin preserved as a thin film of weathered iron minerals. This appearance is very similar to the appearance of certain specimens from the Llanfawr Quarries (Botting, 2004) and indicates at least some degree of soft-tissue preservation.

The sponge fauna will be described in detail in future publications, but it is clear that two species are relatively frequent and another reasonably common, but most are rather rare, with at least two known only from isolated spicules. Many of these sponge skeletons would have been disarticulated by slight water movements, and the true abundance and diversity would have been significantly higher than recognised.

\section{Palaeoscolecids (Figure 4.3)}

Palaeoscolecids were armoured worms believed to be closely allied to the priapulids (Conway Morris, 1997; Harvey et al., 2010). Due to their phosphatic sclerites, they are known from a wide range of Cambrian to Silurian localities, with remarkable phosphatised faunas extracted by acid digestion of limestones, as described by, for example, Müller and Hinz-Schallreuter (1993) and Topper et al. (2010). However, their cuticle consisted of numerous microscopic plates and minute platelets, which in most cases disarticulated almost immediately after death. As a result, although specimens can be abundant and exquisitely preserved at some localities, in most places they are not preserved at all. In total, six localities in the Builth Inlier, including the Holothurian Bed, preserve a diverse fauna of palaeoscolecids (Botting et al., in press). In the rest of Britain, palaeoscolecids are known from the Tremadoc Shineton Shale of Shropshire (Whittard, 1953), the Tremadoc Breadstone Shales of Gloucestershire (Whittard, 1953), the early Tremadoc of Clyn-côch, Carmarthenshire (Owens et al., 1982) and the early Ludlow of Herefordshire (Bather, 1920). 
TABLE 1. Complete list of the fauna known from the Holothurian Bed at the time of writing; a total of ten sponge species and two dendroids are included, although the exact numbers may increase on further study. Abundance notes are semi-quantitative: "rare": encountered on three or fewer occasions; "occasional": encountered on fewer than half of collecting trips; "frequent": encountered in low numbers on most collecting trips; "common": encountered on almost all collecting trips, often with several individuals; "superabundant": encountered on almost every slab.

\begin{tabular}{|c|c|c|}
\hline Group & Taxon & Notes \\
\hline \multirow[t]{11}{*}{ Trilobites } & Ogyginus corndensis & Common, including as complete juveniles \\
\hline & Ogygiacarella debuchii & Moderately common \\
\hline & Cnemidopyge parva & Occasional complete moults \\
\hline & Protolloydolithus reticulatus & Occasional \\
\hline & Platycalymene simulata & Rare - one complete meraspis \\
\hline & Rorringtonia kennedyi & Occasional \\
\hline & Geragnostus mccoyii & Occasional \\
\hline & odontopleurid indet. & Rare - one rib fragment \\
\hline & Microparia lusca & Rare - few near-complete adults \\
\hline & Other cyclopygids (indet.) & Rare fragments \\
\hline & Barrandia cordai & Rare \\
\hline \multirow[t]{7}{*}{ Brachiopods } & Apatobolus? micula & Superabundant \\
\hline & Palaeoglossa attentuata & Common \\
\hline & Monobolina ramsayi & Occasional \\
\hline & Opsiconidion nudum & Occasional \\
\hline & Schizocrania cf. salopiensis & Occasional-only encrusting undetermined substrate \\
\hline & Meristopacha granulata? & Rare \\
\hline & Dalmanellid indet. & Rare \\
\hline \multirow[t]{3}{*}{ Graptolites } & Cryptograptus tricornis & Frequent \\
\hline & Hustedograptus? teretiusculus & Occasional \\
\hline & Dendrograptus spp. & Rare; at least two species \\
\hline \multirow[t]{6}{*}{ Echinoderms } & Cystoid indet. & Rare - one specimen and one possible \\
\hline & Anatifopsis? sp. & Common \\
\hline & Galliaecystis? sp. & Rare - fragments of four specimens \\
\hline & Solute undet. & Rare - one articulated specimen \\
\hline & Carpoid indet. & Rare - one specimen \\
\hline & Oesolcucumaria eostre gen. et sp. nov. & Occasional \\
\hline \multirow[t]{2}{*}{ Cnidarians } & Sphenothallus sp. & rare - few specimens \\
\hline & Conulariid indet. & Rare - one specimen \\
\hline \multirow[t]{3}{*}{ Ostracodes } & Undetermined smooth form & Common \\
\hline & Bullaeferum sp. & Occasional \\
\hline & Nanopsis sp. & Occasional \\
\hline Chordates & Conodonts & Occasional as isolated elements; rare as clusters (pellets?) \\
\hline \multirow[t]{3}{*}{ Molluscs } & Bivalve indet & Rare \\
\hline & Gastropod indet. & Rare - few specimens \\
\hline & Nautiloids indet. & Rare - few specimens \\
\hline \multirow[t]{8}{*}{ Sponges } & Pirania? sp. & Rare \\
\hline & Wapkia-like form & Occasional \\
\hline & Xylochos? sp. & Occasional \\
\hline & Reticulosan sp. 1 & Frequent \\
\hline & Reticulosan sp. 2 & Frequent \\
\hline & Hexactinellid indet. & Rare \\
\hline & Sponges undet. (several spp.) & Rare \\
\hline & Eiffeliid indet. & Isolated spicules only \\
\hline \multirow[t]{3}{*}{ Worms } & $\begin{array}{l}\text { Palaeoscolecid gen. et sp. nov. (Botting } \\
\text { et al. in press) }\end{array}$ & One confirmed specimen; many too poorly preserved to identify \\
\hline & Palaeoscolecid undet. & One specimen with different plating to Palaeoscolecid gen. et sp. nov. \\
\hline & Scolecodonts & One associated pair of elements \\
\hline Undet. & Algal remains? & Remains on which ostracodes are feeding \\
\hline
\end{tabular}


The excavation of the Holothurian Bed has so far yielded 18 specimens of palaeoscolecids. The specimens are generally narrow $(0.4-0.7 \mathrm{~mm})$, but very long (longest fragment over $20 \mathrm{~mm}$ ); despite preparation of all specimens, neither end of the animal has yet been recovered. Almost all specimens are preserved as orange-weathered iron minerals, with poor cuticular detail, but the distinctive plate annuli are in some cases visible. There is significant thickness to these specimens, suggesting a high level of pyritisation that is unexpected for phosphatic skeletal remains; conodonts are typically mouldic, with little or no iron mineralization. In contrast, there are two short fragments of cuticle preserved without the thick mineralization, and likely to represent moult fragments. moult fragments, suggesting that the thick pyritisation of possibly complete worm fossils resulted from softtissue mineralisation of entire carcasses, whereas the well-preserved cuticle fragments did not have associated labile tissues that induced early mineralisation. It is, therefore, possible that future excavations will yield complete specimens.

The high proportion of non-moults suggests that preservation of articulated specimens was dependent on burial of live animals, with the majority of moulted cuticles destroyed prior to burial. The life abundance was therefore likely to have been much higher than that represented by fossils, as sedimentation rate appears to have been continuously high, but with limited episodes of abrupt burial.

\section{Echinoderms (Figure 5)}

In contrast to shallow-water deposits in the Builth Inlier, in which echinoderms and sponges are abundant (Botting, 2003, 2005), echinoderms are generally rare in the Llanfawr Mudstones Formation. The Nemagraptus gracilis Biozone Llanfawr Mudstones Lagerstätte beds contain rare crinoids (Botting et al., 2011), but the only other confirmed echinoderms known from the upper part of the formation are cornutes, mitrates and an extremely rare Echinosphaerites-like cystoid (two specimens from Llanfawr Quarry reportedly in private collections). At another site, in the middle $H$. ? teretiusculus Biozone, there is a local fauna of carpoids that is under description, another in the $N$. gracilis Biozone, and rare fragments also occur at a site in the upper $D$. murchisonii Biozone (Conway and Botting, in press).

The echinoderm fauna from the Holothurian Bed consists predominantly of a single carpoid species, the mitrate Anatifopsis? sp. (probably the same species as occurs elsewhere in the formation) (Figure 5.1), which is one of the most abundant fossils. Although most of the remains are fragmentary, several articulated specimens are known. Cornute remains are rarer, but fragments of several individuals are known, most of them collected from one small area of the outcrop. A single specimen of an undescribed solute has also recently been collected by C. Upton (personal commun., 2011), and additional undetermined carpoids are also present (Figure 5.2). The holothurians (described in detail below) are rare, with four partial or complete articulated specimens and four isolated calcareous rings that may or may not belong to the same species. Holothurians superficially resemble sponges in appearance and presence of cruciform sclerites, but are easily recognised by the presence of a distinct oral ring. The only other echinoderm fossil is a single very small ( $3 \mathrm{~mm}$ in diameter) cystoid theca with radially ridged plates (Figure 5.3), which requires further material for a full description.

\section{Graptolites (Figure 6)}

Although not abundant, graptolites form a significant component of the fauna, the most common species being the diplograptid Cryptograptus tricornis (Figure 6.1). There are occasional specimens of Hustedograptus? teretiusculus (Figure 6.2), indeterminate climacograptids and dendroids (Dendrograptus? spp., Figure 6.3). The preservation of graptolites is often rather faint, and they may have been more abundant in life but with many having been destroyed by decay or oxidation. Siculae are more abundant than mature rhabdosomes.

\section{Brachiopods (Figure 6)}

Brachiopods are almost exclusively represented by phosphatic groups, and by far the most abundant species in the fauna is the obolid Apatobolus? micula (Figure 6.6). This species is known to be both benthic and pseudoplanktic (Botting and Thomas, 1999), with both life habits occurring simultaneously within this section (Botting, 2000). Other common brachiopod species are Palaeoglossa attenuata (Figure 6.4), and the less common Monobolina ramsayi, Schizotreta sp. (restricted to encrusting hard substrates, Figure 6.5) and the acrotretid Opsiconidion nudum. There are rare specimens of a larger lingulid (possibly Meristopacha granulata), and the only rhynchonelliforms are very rare orthids. 


\section{Cnidarians}

Rare specimens of conulariids are found in the mudstones underlying the tuff below the Holothurian Bed and lower in the sequence, with one specimen from the Holothurian Bed itself, but other cnidarians are limited to rare Sphenothallus specimens. These are small, tubular forms that are invariably isolated. Preservation is typically good, with black reflective material assumed to represent original phosphate, and sphenothallid abundance has probably not been significantly underestimated.

\section{Ostracodes}

Ostracodes or ostracode-like carapaces are locally abundant and generally frequent in the Bach-y-Graig section. A smooth, undescribed form is the most common type in the Holothurian Bed. These are often preserved either articulated, or with the valves associated, almost always as moulds. Rarer species include the binodicopes Bullaeferum sp. and Nanopsis sp. The diversity of ostracodes in the Holothurian Bed is much lower than that found lower in the Bach-y-Graig section. There should be little preservational bias against these carapaces in the preserved record, although there may be collector bias as a consequence of their small size.

\section{Other Microfossils}

Microfossils have not been studied, but they include abundant chitinozoans and rare conodonts. One cluster of conodonts has been found, although with no trace of original arrangement, implying a faecal pellet rather than an articulated bedding plane assemblage.

\section{ECOLOGY OF THE HOLOTHURIAN BED}

\section{Reconstructed Life Abundances}

Despite the problems inherent in using a correction factor, we argue that this method gives a far better impression of the life assemblage of the community than considering only the raw data. Table 2 shows the preserved abundance and estimated life abundance (derived from the technique explained in Materials and Methods) of the organisms recovered from the holothurian bed. Excluding $A$ ? micula, the most common preserved animal is the mitrate Anatifopsis?, with sponges and ostracodes next most abundant. In life, however, sponges were the most abundant, followed by palaeoscolecids.
Trilobites allow two independent estimates of abundance. If we considered only non-moulted complete carcasses (approximately 10), an extrapolated abundance of 210 is estimated. If instead we include articulated moults (around 50 specimens), and allow a modification to allow for five moults per individual, the resulting estimate is slightly higher (250). As discussed in the Materials and Methods section, both of these values should be regarded as maximum estimates, and the true relative abundance is therefore likely to be less than 200.

For most organisms at the end of the hollow curve of species abundance (e.g., gastropods, bivalves) both preserved and life abundances were low. The tail of the curve includes some of the most easily preservable skeletons, indicating that this is a genuine result; the life assemblage was instead dominated by taxa with delicate and multi-element skeletons. Graptolites are also remarkably rare in the reconstructed life assemblage; however, this may be partly a taphonomic signal (preservation is often as faint reflective films, and some proportion may have been lost completely), or the planktic graptolites may have undergone additional biostratinomic processing, such as decay before reaching the sea floor. Conodont animals may have been transitory members of the fauna, and isolated elements are probably often overlooked; they have not been included in the analysis.

\section{Trilobite Clusters}

Small clusters of particularly juvenile trilobites (recognised as being those without a full complement of thoracic ribs) are not uncommon in the fauna and are sometimes associated with other fossils, notably ostracodes. The juvenile trilobites are a mixture of moults, disarticulated fragments and apparently complete specimens, which may indicate that the trilobites were seeking a safe place to moult, or combining this with feeding on decaying organic matter that has not been preserved. The latter would accord with the co-occurrence of ostracodes, which are seen to exhibit scavenging behaviour in the Holothurian Bed (discussed in Trophic relationships, below).

Clusters of trilobites preserved on bedding planes have been recorded widely from other places and times (e.g., Karim and Westrop, 2002; Paterson et al., 2007 and references therein). Monospecific trilobite clusters have been interpreted as recording an aspect of trilobite behaviour, in that the trilobites are thought to have aggregated for moulting and reproduction (Karim 
TABLE 2. Approximate proportions of the fauna in terms of collected and life abundance, based on largely non-analytical collecting over 10 years; the figures are therefore not rigorous, but instead estimated values from our observations. The correction factor is based on the ratio of articulated to fragmented scleritomes of Anatifopsis?, representing the proportion of individuals affected by rapid burial, which was then applied to other multi-element scleritomes. Deviations from this factor were employed to allow for ecdysis and additional requirements of soft-tissue preservation; see text for more details.

\begin{tabular}{|c|c|c|c|c|}
\hline & complete (c) & $\begin{array}{l}\text { disarticulated } \\
\text { (d) }\end{array}$ & $\begin{array}{l}\text { Correction } \\
\text { factor }\left(C_{i}\right)\end{array}$ & $\begin{array}{c}\text { Estimated relative } \\
\text { life abundance }=c\left(C_{i}+1\right)\end{array}$ \\
\hline Apatobolus? micula & $>100$ & Many & & $>>1000$ \\
\hline sponges & 50 & Not visible & 20 & 1050 \\
\hline palaeoscolecids & 17 & 2 fragments & $\sim 20$ & 357 \\
\hline trilobites & $\begin{array}{l}10 \text { (non-moult) } \\
50 \text { (moults) }\end{array}$ & $?$ & $\begin{array}{c}20 \\
20 / 5=4\end{array}$ & $\begin{array}{l}<210 \\
<250\end{array}$ \\
\hline ostracodes & 30 & Many & $20 / 4=5$ & 180 \\
\hline holothurians & 8 & Not visible & $20+$ & $>168$ \\
\hline mitrates & 7 & $\sim 140$ & 20 & $\sim 147$ \\
\hline other brachiopods & $?$ & 100 & - & 100 \\
\hline graptolites & 80 & $n / a$ & - & 80 \\
\hline solutes & 1 & Not visible & 20 & 21 \\
\hline bivalves & 5 & $\mathrm{n} / \mathrm{a}$ & - & 5 \\
\hline cornutes & 0 & 4 & - & 4 \\
\hline nautiloids & 3 & $\mathrm{n} / \mathrm{a}$ & - & 3 \\
\hline sphenothallids & 3 & $n / a$ & - & 3 \\
\hline gastropods & 2 & $\mathrm{n} / \mathrm{a}$ & - & 2 \\
\hline
\end{tabular}

and Westrop, 2002). The latter reason for aggregating can only apply to mature specimens in monospecific assemblages, unlike the examples from the Holothurian Bed, but juvenile trilobites may well also have moulted gregariously. Most of the trilobite clusters recorded in the literature consist of at least several dozen individuals (e.g., Karim and Westrop, 2002; Paterson et al., 2007), and are monospecific, whereas the clusters at Bach-y-Graig consist of fewer than 10 individuals and can contain more than one species. If the Holothurian Bed aggregations were for the purpose of seeking shelter during moulting, and the trilobites were sheltering under something on the sea floor, the small number of trilobites per cluster is not surprising. The polyspecific nature of the cluster is perhaps a little more unexpected. However, clustering behaviour is known to be a feature of many trilobite clades (Paterson et al., 2007), and there is no obvious reason why trilobites would seek out their own species in preference to others, if they were not seeking to mate and the other trilobites were not likely to eat them. We therefore conclude that this pattern at Bach-y-Graig likely reflects moulting behaviour, and that they were probably sheltering beneath organic materials that are not preserved. Cases are known in which both the trilobite and the shelter have been preserved
(Brett, 1977; Davis et al., 2001; Chatterton et al., 2003), and it should be expected that cases in which only the trilobites are preserved would be found. Among modern arthropods, there is a similar tendency to shelter during moulting expressed by groups as diverse as Antarctic collembolans (Worland et al., 2006) and reef-dwelling stomatopods (Reaka et al., 1989).

\section{Trophic Relationships}

Feeding habits and trophic specialisms of fossil organisms are often difficult to obtain evidence for, even in broad terms. For example, although palaeoscolecidans have been convincingly allied to the predatory priapulids (Conway Morris, 1997), their trophic habit is uncertain. Among Chengjiang taxa, for example, some species appear to have sediment-filled guts, and others do not, suggesting diversity of feeding strategy within the group (Han et al., 2004). Similarly for sphenothallids and conulariids, there is insufficient material to assess their ecology beyond the generic assumption that they were microcarnivores (e.g., Peng et al., 2005). Sponges, brachiopods, graptolites and probably carpoids were suspension-feeders, whereas detritivores and/or scavengers are likely to be represented by ostracodes, many trilobites, and perhaps bivalves and gastropods. Predators are rare in the 


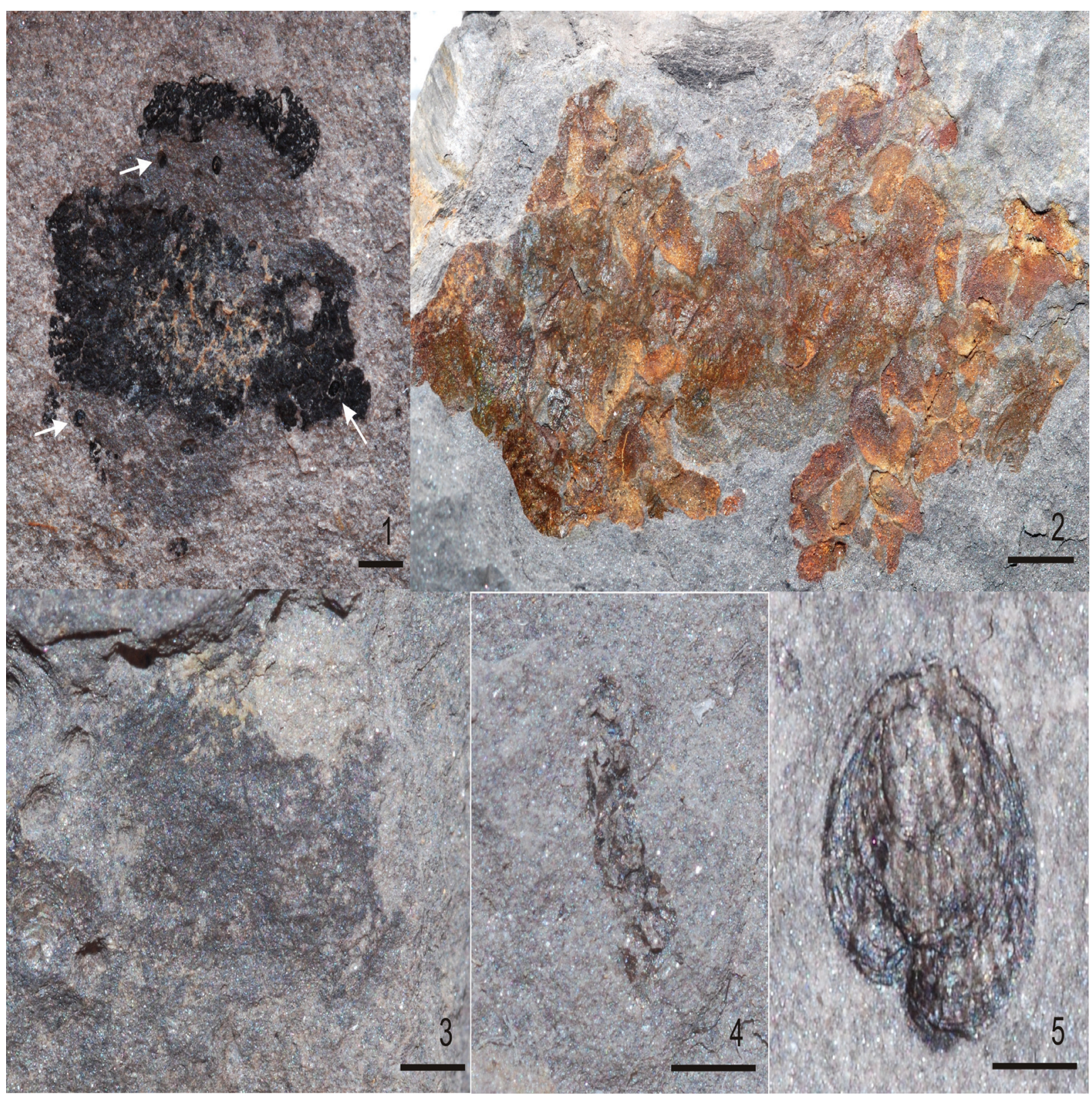

FIGURE 8. Specimens from the Holothurian Bed, Bach-y-Graig showing ecological relationships. 1, organic matter with feeding ostracodes (three examples arrowed) NMW2011.2G.8, scale bar equals $1 \mathrm{~mm}$; 2, Cluster of dissociated Anatifopsis? plates and trilobite sclerites interpreted as possible cephalopod midden, NMW2011.2G.16, scale bar equals $5 \mathrm{~mm}$; 3 , pellet composed of fibrous carbonaceous material NMW2011.2G.23, scale bar equals $1 \mathrm{~mm}$; 4 , pellet composed of crushed valves of Apatobolus? micula, NMW2011.2G.24, scale bar equals $1 \mathrm{~mm} ; 5$, Apatobolus? micula showing repair from probable attempted predation damage, NMW2011.2G.37, scale bar equals $1 \mathrm{~mm}$.

fauna, represented by nautiloids, conodont animals, probably some trilobites and possibly gastropods.

It is unusual to obtain direct evidence of trophic relationships in the fossil record. Where they occur, they are usually anecdotal, consisting of individual specimens illustrating a specific relationship (although where numerous such anecdotal occurrences combine, they can be used to construct rigorous treatments of specific trophic relationships). There are several such specimens known from the Holothurian Bed, falling into three categories: clusters, pellets and damage.

The clearest example of trophic interaction is a cluster of 10 articulated ostracodes (an unidentified smooth species that also occurs elsewhere in 
the Holothurian Bed) embedded within a thin organic sheet that represents decaying organic matter of some type (Figure 8.1). Although it is possibly a fragment of a soft-bodied metazoan, the most likely interpretation is algal remains washed in from shallow water, or having sunk from the surface water. The density of the ostracode assemblage, relative to their much lower background abundance, indicates active foraging for detritus. This in turn implies that for this species at least, there was insufficient organic matter within a small area of sediment to support them by simple detritivory. Rather than near-stationary detritivores feeding in situ, these ostracodes were relatively active, mobile scavengers. A similar occurrence has been recorded from Carboniferous deposits, with ostracodes feeding on a shark carcass (Wilby et al., 2005).

Amongst the most common palaeontological data sources relating to invertebrate trophic interactions are faecal pellets (Figure 8.3, 8.4). These are rare in the Holothurian Bed, but highly specific in content. Two examples are composed of the crushed shells of obolid brachiopods, almost certainly $A$ ? micula (Figure 8.4). The pellets are dense masses of coarsely broken shells, within a microcrystalline matrix. There is no evidence of any other component. Because this brachiopod was both pseudoplanktic and benthic (Botting and Thomas, 1999), it is impossible to be certain regarding the habitat of the predator. Durophagy on brachiopods has been reported both in the benthic (e.g., Zhang et al., 2011) and planktic (Freeman and Miller, 2011) realms. The most likely possibilities for brachiopod predators at this time are nautiloids, conodont animals and arthropods (Alexander, 1986; Leighton, 2003 and references therein; Aldridge et al., 2006). Based on the size of the pellets (up to three millimetres long), and the breakage of the shells implying hardened appendages or mouthparts, the most likely predator was some form of arthropod. The pellets are too large to have been made by most conodont taxa, and nautiloids do not produce faecal pellets (see discussion below). Some of the larger trilobites (e.g., Ogygiocarella) would have been large enough to produce such pellets, assuming that they were capable of breaking the shells. Although trilobites lacked chelae or mandibles, modern limulids are capable of crushing bivalves using their gnathobases, which are similar to those in at least some trilobites (Fortey and Owens, 1999), and the small, delicate shells of $A$ ? micula should have been easily broken. However, in the case of Ogygiocarella we should expect the pellets to be much more common. Other trilobites such as calymenids are rare at the site, however, and these could potentially be responsible as the group in general possessed features of the hypostome consistent with predation (Fortey and Owens, 1999). Another probable pellet consists of a cluster of conodont elements, of similar size to the crushed obolid pellets, and this may represent the same or a similar type of predator with at least temporarily different feeding behaviour.

Some brachiopod specimens show evidence of repair after damage (Figure 8.5), indicating that predation was not always successful. The damage is perhaps more consistent with marginal shell breakage using chelae (Freeman and Miller, 2011; Zhang et al., 2011) than with generalised crushing by gnathobases, suggesting that at least this damage was produced by a chelate non-trilobite arthropod. Predators feeding in this way are unlikely to ingest abundant shell fragments, so it is likely that the pellets of broken A.? micula, were produced by a different organism.

Loose concentrations of Anatifopsis? plates are further evidence for apparent feeding activity. Several examples are known, in one case representing at least ten individuals; in some cases (Figure 8.2) trilobite sclerites are included. The density of the cluster and the complete disarticulation makes it unlikely that these are the disarticulated remains of a dense life assemblage, and no plates appear to be broken. The remains include both the largest thecal plates, and also rarer plates from the stylocone, which cannot easily be explained by concentration through winnowing of scattered plates. The areas covered by plates are irregular in shape, but not elongate as would be expected for debris between ripples. The concentration of the plates in one small area suggests a predator specialised in feeding on the mitrates (which are common but not ubiquitous), and which had a permanent living area or territory to which it returned to feed. This precludes pelagic organisms, but either nektobenthic cephalopods or arthropods are plausible.

A nautiloid producer of these mitrate plate concentrations is most likely. We have been unable to find any references for what nautiloid coprolites would be expected to look like, or any information on modern nautiloid faeces. Zangerl et al. (1969) reported structures that they interpreted as nautiloid coprolites, without providing any definite evidence for this view. Structures have been reported from the Soom Shale that may be the coprolites of 
nautiloids (Aldridge et al., 2006), but this interpretation is based only on the presence of nautiloids within the deposit, rather than any characteristics of the structures themselves. Modern nautiloids do not produce recognisable pellets in aquaria, instead producing amorphous or stringy material (Bruce Carlson, personal commun., 2011), and octopus also do not produce recognisable pellets; internal tissues of prey are often liquefied using venom, leaving mineralised plates intact (D. Whatley, personal. commun., 2011). Many modern octopodes are known to produce 'middens' of shelly debris (e.g., Vincent et al., 1998), as they do not ingest hard sclerites, and their foraging behaviour tends to focus on the most common available prey species (Leite et al., 2009). The absence of discrete pellets associated with the midden-like accumulations in the Holothurian Bed therefore suggests a nautiloid rather than arthropodan predator. While interpreting the behaviour of extinct taxa on the basis of their extant distant relatives must be done with care, in this case it does show that cephalopods represent a plausible producer of these concentrations of mitrate debris.

\section{Comparison with Other Community Types}

Direct comparisons of the Holothurian Bed community with other communities are limited by the unusual combination of groups comprising the bulk of the assemblage. Obolid brachiopods are nearly ubiquitous in Ordovician mudstones, but the next most abundant group is non-lithistid, spiculate sponges. Offshore faunas dominated by sponges are known even within the Builth Inlier (Botting, 2004), and abundant reticulosan sponge faunas have been described to dominate some other Early Palaeozoic benthic communities (e.g., Rigby and Harris, 1979; Rigby et al., 1991). These examples are typical of diverse sponge faunas from offshore facies in that few other taxa besides graptolites are present. In the younger Llanfawr Mudstones Lagerstätte at Llanfawr Quarries (Botting, 2004; Botting et al., 2011), the sponges are associated particularly with solitary, athecate hydrozoans; echinoderms are extremely rare, and palaeoscolecidans unknown. The combination of sponges with abundant carpoid echinoderms is extremely unusual; where both co-occur frequently (e.g., Van Roy et al., 2010), they are associated with a diverse, normal marine shelf fauna and neither group is a dominant component of the biota. Conversely, where carpoids are abundant, they tend to dominate faunas alone, or combined with ophiuroids (Lefebvre, 2006). Faunas with abundant palaeoscolecids are extremely scarce, and they represent a dominant ecological component only in some assemblages of the early Cambrian Chengjiang Biota (Han et al., 2006).

Ordovician shallow-water faunas from siliciclastic settings can have a major component of sponges and echinoderms (Botting, 2003, 2005), but the groups represented in both cases are very different (thick-walled, lithistid and agglutinating sponges; echinoderms mostly crinoids and cystoids with rarer edrioasteroids, asteroids and other groups) and morphologically capable of withstanding the higher-energy conditions above normal wave-base. Such shallow-water faunas also tend to include abundant rhynchonelliform brachiopods, bryozoans, and in later faunas, corals and stromatoporoids. Molluscs also tend to be much more abundant (where preserved), including diverse bivalve and gastropod faunas, and large nautiloids. The same generally applies to shallow-water carbonate-hosted assemblages, except that the sponge faunas are more strongly dominated by lithistids and hypercalcified taxa (e.g., Pratt and James 1982; Harland et al. 1987).

In comparisons with extant communities, there is some similarity to the abyssal plain: a high proportion of filter-feeding echinoderms and hexactinellid sponges, and large numbers of opportunistic and mobile taxa, and some predators that appear to have been specialist. It does not closely resemble the dense sponge associations of the deep ocean, where most taxa are sessile (e.g., Beaulieu, 2001) and the fauna is more similar to that described by Botting et al. (2011), but is perhaps closer to the intervening areas of seafloor, which are often dominated by holothurians or ophiuroids (Brandt et al., 2007).

\section{CONCLUSIONS}

The Holothurian Bed represents a short interval of disturbed ecology following a large-scale ash-fall (or redeposition) in offshore conditions on the flanks of a volcanic island. Intensive collecting of the biota from this $50 \mathrm{~cm}$ thick interval has revealed a diverse fauna of around 50 species (Figure 7 ), including examples of rarely preserved groups, and evidence for ecological interactions. Contrary to expectations of a trilobite-dominated fauna, the most abundant organisms were suspension feeders (brachiopods, sponges, possibly carpoids), then presumed detritivores or scavengers (ostracodes, palaeoscolecidans, trilobites, holothurians and possibly carpoids). Some of these groups require a degree of exceptional preserva- 
TABLE 3. Expected taxonomic composition of the preserved fauna under different degrees of preservation. "Poor preservation" implies an entirely disarticulated and washed assemblage of shelly fragments. "Moderate preservation" implies a fauna lacking abrupt burial and soft tissue, but without extended sea-floor exposure or winnowing. The observed fauna is extensive, but will inevitably be increased by further collecting, as taxa from the tail of the hollow curve are discovered. The total diversity of macrobiota in the local area at the time of deposition is impossible to ascertain, but it was likely to have been in excess of 100 species, by comparison with major Lagerstätten such as the Fezouata Biota (Van Roy et al., 2010) and the Burgess Shale (Conway Morris, 1986). In these deposits, many taxa are localised, and were found only after extensive collecting.

\begin{tabular}{|c|c|c|c|}
\hline Complete biota & Holothurian Bed & Moderate preservation & Poor preservation \\
\hline Trilobites $(\geq 11 \mathrm{spp})$ & Trilobites (11 spp) & Trilobites (11 spp) & Trilobites (<11 spp, frag.) \\
\hline Brachiopods ( $\geq 7 \mathrm{spp}$ ) & Brachiopods (7 spp) & Brachiopods (7 spp) & Brachiopods ( $\leq 7 \mathrm{spp})$ \\
\hline Other shelly taxa ( $\geq 8 \mathrm{spp}$ ) & Other shelly taxa (8 spp) & Other shelly taxa (8 spp) & Other shelly taxa (<8 spp) \\
\hline Graptolites ( $\geq 5 \mathrm{spp}$ ) & Graptolites (5 spp) & Graptolites (5 spp) & Graptolites ( $\leq 5 \mathrm{spp})$ \\
\hline Sponges ( $\geq 10 \mathrm{spp})$ & Sponges (10 spp) & Sponges (spicules only) & Sponges (spicules only) \\
\hline Conodonts ( $\geq 1 \mathrm{sp}$. ) & Conodonts (1 sp.) & Conodonts (1 sp.) & Conodonts (1 sp.) \\
\hline Carpoids etc. ( $\geq 3 \mathrm{spp}$ ) & Carpoids ( $3 \mathrm{spp}$ ) & Carpoids (2 spp) & Anatifopsis? plates only \\
\hline Cystoids ( $\geq 1 \mathrm{sp}$. ) & Cystoids (1 sp.) & - & - \\
\hline Algae ( $\geq 1 \mathrm{sp}$.) & Algae? (1 sp.) & - & - \\
\hline Holothurians ( $\geq 1 \mathrm{sp}$.) & Holothurians (1 sp.) & - & - \\
\hline Palaeoscolecidans ( $\geq 2 \mathrm{spp}$ ) & Palaeoscolecidans (2 spp) & - & - \\
\hline Unmineralised arthropods & - & - & - \\
\hline Unmineralised worms & - & - & - \\
\hline Other soft-bodied taxa & - & - & - \\
\hline Estimated total: & 51 & 35 & $<30$ \\
\hline
\end{tabular}

tion in order to be preserved, and we have had to make use of a new approach involving correction factors to estimate their relative life abundance.

The exceptionally preserved elements are in large part difficult or poorly studied groups (e.g., sponges, palaeoscolecidans, carpoids), and these groups form a major part of the fauna; the more obvious fossils such as trilobites are only moderately important. In summarising the available information, it is possible to partly interpret the life assemblage, giving an unusual perspective on an Ordovician community. Although this interpretation is very incomplete, with only rare examples of unmineralised organisms and occasional direct ecological links preserved, this is substantially more than is usually accessible.

Faunas that lack such exceptional preservation or show only certain elements of it (such as articulated material but not soft tissue) will yield a very biased assemblage that will not give any indication of the entire biota. Even in the Holothurian Bed there is no evidence of non-biomineralised arthropods or entirely soft-bodied organisms, although some of the preservation suggests that they should be expected to have been preserved at least occasionally. Fragments of unmineralised arthropod exuviae in particular should have been preserved, and their absence suggests genuine rarity in the life community. The presence of soft tissue shadows in the holothurians implies that at least some entirely soft-bodied organisms should have been preserved if they had formed significant components of the life assemblage. Table 3 shows a schematic impression of the expected composition of the biota under different preservation conditions. The data show do not take into account differential preservation potential of aragonite versus calcite in some settings (Cherns and Wright, 2000) or taphonomic differences due to shell structure (as seen in modern brachiopods; Tomašovych and Rothfus, 2005), which may further reduce the diversity seen in a "normal" assemblage. Although over half of the taxa should be recorded even in deposits yielding only disarticulated fragments, the composition of this assemblage would be predominantly the more robust biomineralised taxa, giving the impression of a trilobite- or brachiopod-dominated community. The elements that give the fauna its unexpected ecological character (particularly sponges, carpoids, palaeoscolecids and holothurians) are the elements that would not be preserved under more destructive taphonomy.

In conclusion, the preservation of some exceptional components of the biota, combined with collections of the total fauna rather than focusing on a particular group, have enabled a significant re-evaluation of an ostensibly typical Ordovician offshore community. The unexpected 
character of the fauna might be specific to this deposit, but may instead illustrate a standard community type in Ordovician mudstones; the assemblage expected from a less well-preserved fauna would resemble that of typical trilobitic mudstones. In the latter case, similar exceptionally preserved faunas should yield some evidence for the groups that dominate in the Holothurian Bed, or at least trophic equivalents of them.

At this stage, the inescapable conclusion for those studying the Ordovician Radiation in particular is that we should be extremely cautious about interpreting ecology based on superficial samples of a community and the published record, or of labelling offshore community types according to standard views. Those standards, it seems, are dramatically over-simplistic. Even if there is no evidence available for soft-bodied taxa in a given fossil community, we can no longer assume that superficially similar Ordovician shelly faunas in offshore environments were broadly equivalent as life assemblages. In the same formation, for example, a similar reinterpretation (Botting et al., 2011) of an ostensibly graptolitic-trilobitic assemblage of the Llanfawr Quarries has shown that to contain instead abundant sponges and hydrozoans. Where exceptional preservation is not available, it may be possible to use subtle differences between the shelly fossil assemblages as proxies for deeper differences between communities, although much more work is necessary before this can be assessed as a possibility. We recommend that similar studies be made of the total fauna of any communities with even limited exceptional preservation from Ordovician deposits, to establish whether any consistent patterns are discernible.

\section{SYSTEMATIC PALAEONTOLOGY}

Specimens of the holothurians and the associated illustrated fauna are deposited in the Natural History Museum, London (NMW) and the National Museum of Wales, Cardiff (NMW).

\section{Phylum ECHINODERMATA Class HOLOTHUROIDEA \\ Order and family unknown \\ Genus OESOLCUCUMARIA gen. nov.}

Type species. Oesolcucumaria eostre gen. et sp. nov., designated herein.

Etymology. From the Welsh oesol: ancient.

Diagnosis. Small (c. $10 \mathrm{~mm}$ or less), globular holothurians with multi-plated ring and short, partly skeletonised, uniserial ambulacrae with monaxial sclerites. Body sclerites appear at least partly cruciform.

Remarks. The presence of a calcareous ring unequivocally identifies the new species as a holothurian, and the presence of multiple internodals suggests a relationship to the modern Apodida; some members of the family Synaptidae have more than five interradial plates in the calcareous ring (Kerr and Kim, 2001). However, modern apodans do not have tube feet (Kerr, 2001), whereas this holothurian can be inferred to have possessed them, based on the presence of ambulacra. Also, sclerites attributed to apodans are not known in the fossil record before the Middle Devonian (Kerr, 2001 and references therein). The species described here is the oldest articulated holothurian yet known, and therefore should not be expected to necessarily conform to divisions in the extant fauna.

Several features of the new holothurian are unusual. The skeletal expression of ambulacra is a previously undescribed, presumed primitive feature among holothurians, although short rows of plated tube-feet are present in Palaeocucumaria (Smith, 1988a). An early-branching form might be expected to share this with echinozoan (stemgroup echinoid) ancestors, except that current views on the origin of the calcareous ring suggest that it was derived from the ambulacral plate sequence (Haude, 1995), and the tube foot rows to have been independently evolved among non-apodan holothurians (David and Mooi, 1996).

Alternatively, the calcareous ring could have been derived from a structure homologous to the Aristotle's Lantern of echinoids (Littlewood et al., 1997). Haude (1994) provided a hypothetical evolutionary series for the origin of the ring from the ambulacral plates, which involved a transition from a biserial ambulacrum, as found in echinoids, to a uniserial one. Evidence from the calcareous ring plate structure of a Devonian holothurian from South America supports the derivation of the ring from the ambulacra (Haude, 1995). Until now, no holothurian fossil has been reported to possess skeletal ambulacra; although many modern and fossil forms do possess rows of tube-feet down the body, these are not expressed by skeletal tissues.

The ambulacral plate series in the new species appears here to have been, at least in part, reduced to transverse uniaxial sclerites, assuming that these are homologous with echinozoan ambulacral plates. The coincidence of the uniserial arrangement conforming with Haude's (1994) hypothesis of skeletal homologies suggests that 
his interpretation is broadly correct, and the shortness of the ambulacra (here, and more particularly in Palaeocucumaria) may reflect the co-opting of the anterior plates into the ring complex. The complete longitudinal tube foot rows without skeletal ambulacrae of most modern holothurians may therefore indeed be a secondary development, either an extension of the remnant ambulacral series, or an independent origin.

From this species, the timing of holothurian origins clearly predates the Middle Ordovician, but by the Devonian there is already significant diversity. The cross-shaped sclerites preserved in the species described are similar to the sclerites of modern Elasipodida (see, for example, Hansen, 1975). They do not resemble the isolated holothurian sclerites from the Llanvirn illustrated by Reich (2001), which were probably from the orders Dendrochirotida, Dactylochirotida and/or Aspidochirotida. The presence of three or four order-level groups in these earliest faunas show that there was significant diversification of holothurians by the Middle Ordovician (see also Reich, 2010). Given the rarity of fossilization of complete holothurians, or even of their sclerites, we can do little more than limit the youngest possible time of appearance from the fossil record. If the enigmatic Burgess Shale organisms Redoubtia and Portalia, and perhaps even the problematic eldonioids, are also holothurians, then their record would predate by some margin the earliest asterozoans (asteroids and ophiuroids). However, Eldonia at least shows no definitive holothurian features (Smith, 1988b), and the other examples are doubtful (Madsen, 1957). Asterozoans are currently believed to be the sister group of Echinoidea + Holothuroidea, although the exact topology of the relationship is uncertain (Janies, 2001); the earliest fossil asterozoans currently known are of Early Ordovician age (Shackleton, 2005).

The earliest published echinoid-like forms are from the Middle Ordovician (bothriocidaroids) and early Late Ordovician (Smith and Savill, 2001). As with the earliest asterozoans, their unexpectedly high diversity and lack of precursors suggest a relatively deep unknown history, originating at the latest in the Early Ordovician (Smith and Savill, 2001). As a result of the uncertainty over the origin of echinoids, it is only possible to say that the sister group Holothuroidea evolved at least by the Early Ordovician. We might also reiterate that the lack of asterozoans and echinozoans from the Upper Cambrian is very surprising, unless all extant echinozoan classes evolved within a very short period in the Early Ordovician. This gap in our knowledge may be due, at least in part, to environmental preferences of the early echinozoans and asterozoans; it is possible that many members of these groups underwent their early evolution either in nearshore siliciclastic facies (Botting, 2003) or offshore, muddy environments, rather than the carbonate platforms on which the bulk of research has been conducted. If their early representatives were also significantly smaller than younger examples, as seen here, then they may also be easily overlooked. For holothurians, exceptional preservation is clearly required to yield complete specimens, and this also limits the possible sources of information.

\section{Oesolcucumaria eostre sp. nov.}

\section{Figure 9}

Holotype. NHM EE8734 (Figure 9.1), flattened specimen showing the calcareous ring, the body outline and sclerites, from the late Darriwilian (Ordovician) of the Holothurian Bed (defined herein), Bach-y-Graig, Llandrindod, Wales.

Paratypes. One near-complete specimen (NMW2011.2G.21, Figure 9.6), a specimen with calcareous ring and partial body outline (NHM EE8736, Figure 9.4), and a third (NHM EE8737, Figure 9.5) shows traces of the anterior part of the body only. Four articulated calcareous rings with no trace of the body outline have also been recovered (NHM EE8738, EE8739 (Figure 9.7), NMW 2011.2G.10, NMW2011.2G.22). All specimens are from the same locality as the holotype. The holotype has yielded most of the useful information; NHM EE8736 is larger and poorly preserved, but has dimensions approximately twice those given below.

Etymology. After Eostre, Celtic Goddess of the Spring, after whom Easter is named. The first specimen was discovered on Easter Sunday 2005, and the egg-like shape adds to the appropriateness.

Diagnosis. As for genus.

Description. Measurements refer to the holotype NHM EE8734 (Figure 9.1-9.3) unless otherwise stated. It should be assumed that compression of the bodies has led to slightly distorted dimensions; original body form would have been slightly narrower relative to length. Elongate-globular holothurian with uniserial, skeletal ambulacra and a multiplated calcareous ring. Dermal sclerites are primarily cruciform; ambulacral sclerites appear rodshaped. Body is $5.5 \mathrm{~mm}$ long, with maximum width $4.0 \mathrm{~mm}$. The widest point is approximately one- 

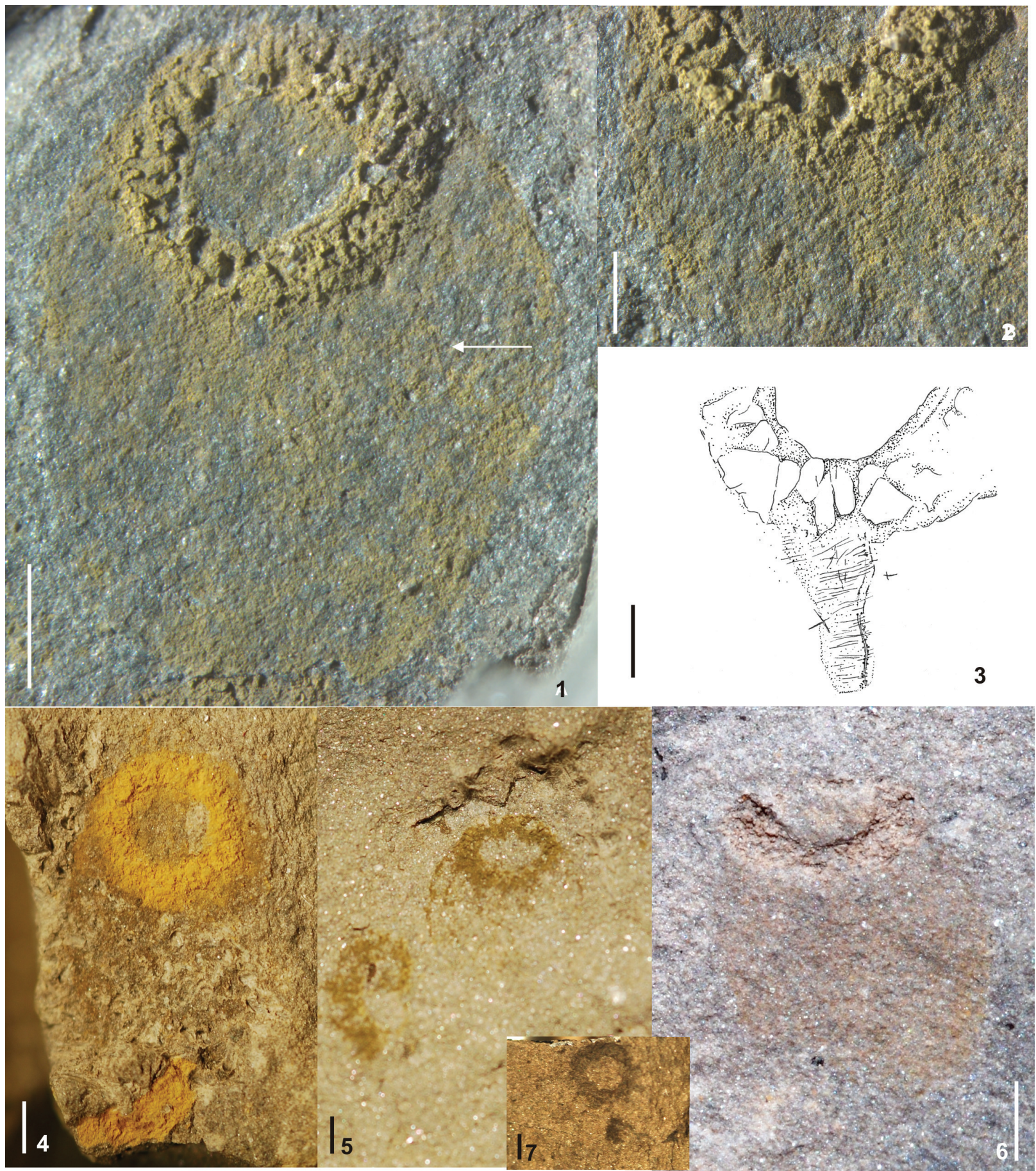

FIGURE 9. Holothurian Oesolcucumaria eostre gen. et sp. nov. 1-3, holotype NHM EE8734; 1, overall view; 2, detail of part of calcareous ring and short ambulacrum; 3; camera lucida drawing of area illustrated in 3; 4, paratype NHM EE8736, large weathered specimen, near-complete; 5, paratype NHM EE8737, anterior part of holothurian showing weakly pyritised oral ring and possibly also ambulacral structures; 6, paratype NMW2011.2G.21, complete weathered specimen with poorly preserved fine detail; 7, paratype NHM EE8739, isolated calcareous ring. Scale bar equals 1 $\mathrm{mm}$. 
third of the way to the posterior, which is blunt and rounded. Paratype NMW2002.2G.21 (Figure 9.6) is $3.8 \mathrm{~mm}$ long by $2.8 \mathrm{~mm}$ wide, the widest point also roughly one-third of the way to the posterior; the poor, semi-complete specimen NHM EE8737 (Figure 9.5) also suggests similar proportions. The available specimens therefore indicate a compressed length to width ratio of around 1.3-1.4:1.

The calcareous ring is $2.8 \mathrm{~mm}$ in external diameter and $1.4 \mathrm{~mm}$ in internal diameter $(2.1 \mathrm{~mm}$ and $1.1 \mathrm{~mm}$ in NMW2002.2G.21); the same ratio of almost exactly $2: 1$ occurs in other specimens. The internal margin forms a rounded pentagon, with the external margin less clearly preserved, but subrounded. Nodals are large, wedge-shaped and positioned at the apices of the internal pentagon. Each pair is separated by apparently five internodals, each rounded rectangular, and those adjacent to nodals aligned with nodal sides to produce distinct convergence of internodals away from the centre (Figure 9.2, 9.3).

Ambulacra (Figure 9.2, 9.3) are faintly preserved in places, visible through the presence of densely packed, transversely arranged uniaxial sclerites. Sclerites are usually weakly preserved, but in one ambulacrum (Figure 9.2, 9.3) can be traced over approximately one-quarter of the body length, where the ambulacrum appears to terminate. The ambulacrum, as defined by the sclerites, is $0.5 \mathrm{~mm}$ wide. The uniaxial sclerites are overlain by small, fine-rayed cross-shaped sclerites, very similar to those of reticulosan hexactinellid sponges. The typical orientation of the crosses is diagonal to the uniaxial sclerites, and oblique to the body axis. Further cross-shaped structures, including one with rays $0.3 \mathrm{~mm}$ long, are scattered over the surface; although the positions of the ambulacra are mostly obscure, the crosses appear to be present over the entire surface, and not restricted to ambulacral regions. Very small crosses are faintly visible in several areas. There is no evidence of anterior tentacles in any specimen.

Occurrence. From 5 to $40 \mathrm{~cm}$ above the top of the prominent tuff bed in locality BG2 of Botting (2000), Bach-y-Graig section, Llandrindod, Wales; early $H$.? teretiusculus Biozone, late Darriwilian, Ordovician. Grid reference SO 07106102.

\section{ACKNOWLEDGMENTS}

Much of the ecological data has been collected with the assistance of T. Ormrod, V. Stephens, C. Upton and other volunteers. We thank M. Reich for helpful discussion on the holothurians,
D. Evans for pointing us in the right direction for the nature of nautiloid droppings, and the participants at www.tonmo.com cephalopod forums for confirming his suggestions. JPB's research is supported by the Chinese Academy of Sciences Fellowships for Young International Scientists, grant number 2010Y2ZA03 and the National Natural Sciences Foundation of China Young International Fellowships Grant No. 41150110152. LAM's research is supported by China Postdoctoral Science Foundation, grant number 20110490136. This study was partially supported by the Project-Oriented Hundred Talents Programme (grant number KZCX2YW-BR-23). The manuscript was greatly improved by the careful and thorough reviews of C.L. Schneider and an anonymous reviewer.

\section{REFERENCES}

Aldridge, R.J., Gabbott, S.E., and Theron, J.N. 2001. The Soom Shale, p. 340-342. In Briggs, D.E.G. and Crowther, P.R. (eds.) Palaeobiology II. Blackwell Science, Oxford.

Aldridge, R.J., Gabbott, S.E., Siveter, L.J., and Theron, J.N. 2006. Bromalites from the Soom Shale Lagerstätte (Upper Ordovician) of South Africa: palaeoecological and palaeobiological implications. Palaeontology, 49:857-871.

Alexander, R.R. 1986. Resistance to and repair of shell breakage induced by durophages in Late Ordovician brachiopods. Journal of Paleontology, 60:273-285.

Álvaro, J.J., Vennin, E., Villas, E., Destombes, J., and Vizcaïno, D. 2007. Pre-Hirnantian (latest Ordovician) benthic community assemblages: controls and replacements in a siliciclastic-domated platform of the eastern Anti-Atlas, Morocco. Palaeogeography, Palaeoclimatology, Palaeoecology, 245:20-36.

Bather, F.A. 1920. Protoscolex latus, a new "worm" from Lower Ludlow beds. Annals and Magazine of Natural History Ser. 9, 5:124-133.

Beaulieu, S.E. 2001. Colonisation of habitat islands in the deep sea: recruitment to glass sponge stalks. Deep Sea Research I, 48:1121-1137.

Botting, J.P. 1999. The ecological effects of volcanic ashfall in the marine Ordovician of Central Wales. Acta Universitatis Carolinae: Geologica, 43:499-502.

Botting, J.P. 2000. Palaeoecology and systematics of Ordovician biotas from Welsh volcaniclastic deposits. Unpublished PhD Thesis, University of Birmingham, UK.

Botting, J.P. 2002. The role of pyroclastic volcanism in Ordovician diversification, p. 99-113. In Crame, A.J. and Owen, A.W. (eds). Palaeobiogeography and biodiversity change. Special Publications, Geological Society, London, 194.

Botting, J.P. 2003. Llanvirn (Middle Ordovician) echinoderms from Llandegley Rocks, central Wales. Palaeontology, 46:685-708. 
Botting, J.P. 2004. An exceptional Caradoc sponge fauna from the Llanfawr Quarries, central Wales and phylogenetic implications. Journal of Systematic Palaeontology, 2:31-63.

Botting, J.P. 2005. Exceptionally preserved Middle Ordovician sponges from the Llandegley Rocks Lagerstätte, Wales. Palaeontology, 48:577-617.

Botting, J.P. and Muir, L.A. 2005 (for 2004). The fossil history of the Builth Inlier: insights from a classic area. Transactions of the Radnorshire Society, 74:5084.

Botting, J.P. and Muir, L.A. 2008. Unravelling causal components of the Ordovician Radiation: the Builth Inlier (central Wales) as a case study. Lethaia, 41:111-125.

Botting, J.P. and Thomas, A.T. 1999. A pseudoplanktonic inarticulate brachiopod attached to graptolites and algae. Acta Universitatis Carolinae: Geologica, 43:333-335.

Botting, J.P., Muir, L.A., Sutton, M., and Barnie, T. 2011. Welsh gold: A new exceptionally preserved pyritized Ordovician biota. Geology, 39:879-882.

Botting, J.P., Muir, L.A., Van Roy, P., Bates, D. and Upton, C. in press. Diverse Middle Ordovician palaeoscolecidan worms from the Builth-Llandrindod Inlier of central Wales. Palaeontology.

Brandt, A., De Broyer, C., De Mesel, I., Ellingsen, K.E., Gooday, A.J., Hilbig, B., Linse, K., Thomson, M.R.A., and Tyler, P.A. 2007. The biodiversity of the deep Southern Ocean benthos. Philosophical Transactions of the Royal Society B, 362:39-66.

Brenchley, P.J. and Cocks, L.R.M. 1982. Ecological associations in a regressive sequence: the latest Ordovician of the Oslo-Asker District, Norway. Palaeontology, 25:783-815.

Brett, C.E. 1977. Entombment of a trilobite within a closed brachiopod shell. Journal of Paleontology, 51:1041-1045.

Caron, J.-B. and Jackson, D.A. 2008. Paleoecology of the Greater Phyllopod Bed community, Burgess Shale. Palaeogeography, Palaeoclimatology, Palaeoecology, 258:222-256.

Chatterton, B.D.E., Collins, D.H., and Ludvigsen, R. 2003. Cryptic behaviour in trilobites: Cambrian and Silurian examples from Canada, and other related occurrences, p. 157-173. In Lane, P.L., Siveter, D.J., and Fortey, R.A. (eds.) Trilobites and their relatives. Special Papers in Palaeontology, 70.

Cherns, L. and Wright, V.P. 2000. Missing molluscs as evidence of large-scale, early skeletal aragonite dissolution in a Silurian sea. Geology, 28:791-794.

Cisne, J.L. 1973. Beecher's Trilobite Bed revisited: ecology of an Ordovician deepwater fauna. Postilla, 160:1-25.

Conway Morris, S. 1986. The community structure of the Middle Cambrian Phyllopod Bed (Burgess Shale). Palaeontology, 29:423-467.
Conway Morris, S. 1997. The cuticular structure of the 495-Myr-old type species of the fossil worm Palaeoscolex, P. piscatorum (?Priapulida). Zoological Journal of the Linnaean Society, 119:69-82.

Conway, T.M. and Botting, J.P. in press. Description and ecology of a new Middle Ordovician (Llanvirn) odontopleurid trilobite from the Builth Inlier of mid-Wales, with a review of the genus Meadowtownella. Geological Magazine. DOI: 10.1017/S0016756811000707

David, B. and Mooi, R. 1996. Embryology supports a new theory of skeletal homologies for the phylum Echinodermata. Comptes Rendus de l'Académie des Sciences, Série III, Sciences de la vie, 319:577-584.

Davis, R.A., Fraaye, R.H.B., and Holland, C.H. 2001. Trilobites within nautiloid cephalopods. Lethaia, 34:3745.

Dornbos, S.Q. and Chen, J.-Y. 2008. Community palaeoecology of the early Cambrian Maotianshan Shale biota: Ecological dominance of priapulid worms. Palaeogeography, Palaeoclimatology, Palaeoecology, 258:200-212.

Elles, G.L. 1940 (for 1939): The stratigraphy and faunal succession in the Ordovician rocks of the Builth-Llandrindod Inlier, Radnorshire. Quarterly Journal of the Geological Society, 95:338-445.

Fortey, R.A. and Owens, R.M. 1987. The Arenig Series in South Wales. Bulletin of the British Museum of Natural History (Geology), 41:69-307.

Fortey, R.A. and Owens, R.M. 1999. Feeding habits in trilobites. Palaeontology 42:429-65.

Freeman, R.L. and Miller, J.F. 2011. First report of a larval shell repair scar on a lingulate brachiopod: evidence of durophagous predation in the Cambrian pelagic realm? Journal of Paleontology, 85:695-702.

Frey, R.C. 1987. The palaeoecology of a Late Ordovician shale unit from southwest Ohio and southeastern Indiana. Journal of Paleontology, 61:242-267.

Han, J., Zhang, Z.F., and Liu, J.N. 2004. Taphonomy and ecology of the introverts from the Chengjiang fauna. Journal of Northwest University (Natural Science Edition), 34:208-211.

Han, J., Shu, D., Zhang, Z., Liu, J., Zhang, X., and Yao, Y. 2006. Preliminary notes on soft-bodied fossil concentrations from the early Cambrian Chengjiang deposits. Chinese Science Bulletin, 51:2482-2492.

Hansen, B. 1975. Systematics and biology of the deepsea holothurians. Pt. 1. Elasipoda. Galathea Report, 13:1-262.

Hansen, T., Nielsen A.T., and Bruton, D.L. 2010. Palaeoecology in a mud-dominated epicontinental sea: a case study of the Ordovician Elnes Formation, southern Norway. Palaeogeography, Palaeoclimatology, Palaeoecology, 299:348-362.

Harland, T.L., Pickerill, R.K., and Fillion, D. 1987. Establishment and development of patch reefs in the intracratonic Ordovician sequence near Chicoutimi, Quebec. Lethaia, 20:189-208. 
Harper, D.A.T. 2006. The Ordovician biodiversification: setting an agenda for marine life. Palaeogeography, Palaeoclimatology, Palaeoecology, 232:148-166.

Harvey, T.H.P., Dong, X., and Donoghue, P.C.J. 2010. Are palaeoscolecids ancestral ecdysozoans? Evolution \& Development, 12:177-200.

Haude, R. 1994. Fossil holothurians: constructional morphology of the sea cucumber, and the origin of the calcareous ring, p. 517-522. In David, B., Guille, A., Féral, J.-P., and Roux, M. (eds.) Echinoderms through Time. Balkema, Rotterdam.

Haude, R. 1995. Die Holothurien-Konstruktion: Evolutionsmodell und ältester Fossilbericht. [Constructional morphology of holothurians: evolutionary model and earliest fossil record.] Neues Jahrbuch für Geologie und Paläontologie Abhandlungen, 195:181198.

Holland, S.M. and Patzkowsky, M.E. 2009. The stratigraphic distribution of fossils in a tropical carbonate succession: Ordovician Bighorn Dolomite, Wyoming, USA. Palaios, 24:303-317.

Hughes, C.P. 1969. Ordovician trilobite faunas from central Wales. Part I. Bulletin of the British Museum of Natural History (Geology), 18:39-103

Hughes, C.P. 1971. Ordovician trilobite faunas from central Wales. Part II. Bulletin of the British Museum of Natural History (Geology), 20:115-182.

Hughes, C.P. 1979. Ordovician trilobite faunas from central Wales. Part III. Bulletin of the British Museum of Natural History (Geology), 32:109-181.

Hughes, R.A. 1989. Llandeilo and Caradoc graptolites of the Builth and Shelve inliers. Monograph of the Palaeontographical Society, $89 \mathrm{pp}$.

Janies, D. 2001. Phylogenetic relationships of extant echinoderm classes. Canadian Journal of Zoology, 79:1232-1250.

Johnson, R.G. 1964. The community approach to paleoecology, p. 107-134. In Imbrie, J. and Newell, N.D. (eds.) Approaches to Paleoecology. John Wiley \& Sons, New York.

Jones, O.T. and Pugh, W.J. 1949. An Early Ordovician shoreline in Radnorshire, near Builth Wells. Quarterly Journal of the Geological Society, 105:65-99.

Karim, T. and Westrop, S.R. 2002. Taphonomy and paleoecology of Ordovician trilobite clusters, Bromide Formation, south-central Oklahoma. Palaios, 17:394403.

Kerr, A.M. 2001. Phylogeny of the apodan holothurians (Echinodermata) inferred from morphology. Zoological Journal of the Linnean Society, 133:53-62.

Kerr, A.M. and Kim, J. 2001. Phylogeny of Holothuroidea (Echinodermata) inferred from morphology. Zoological Journal of the Linnean Society, 133:63-81.

Lefebvre, B. 2006. Early Palaeozoic palaeobiogeography and palaeoecology of stylophoran echinoderms. Palaeoceanography, Paleoclimatology, Paleoecology, 245:156-199.
Leighton, L.R. 2003. Predation on brachiopods, p. 215237. In Kelley, P.H., Kowalewski, M. and Hansen, T.A. (eds.) Predator-prey Interactions in the Fossil Record. Kluwer Academic/Plenum Publishers, New York.

Leite, T.S., Haimovici, M., and Mather, J. 2009. Octopus insularis (Octopodidae), evidences of a specialised predator and a time-minimizing hunter. Marine Biology, 156:2355-2367.

Littlewood, D.T J., Smith, A.B., Clough, K.A., and Emson, R.H. 1997. The interrelationships of the echinoderm classes: morphological and molecular evidence. Biological Journal of the Linnean Society, 61:409-438.

Liu, H.P., McKay, R.M., Young, J.N., Witzke, B.J., McVey, K.J., and Liu, X. 2006. A new Lagerstätte from the Middle Ordovician St. Peter formation in northeast lowa, USA. Geology, 34:969-972.

Lockley, M.G. 1983. A review of brachiopod dominated palaeocommunities from the type Ordovician. Palaeontology, 26:111-145.

Madsen, F.J. 1957. On Walcott's supposed Cambrian holothurians. Journal of Paleontology, 31:281-282.

Müller, K.J. and Hinz-Schallreuter, I. 1993. Palaeoscolecid worms from the Middle Cambrian of Australia. Palaeontology, 36:549-592.

Owens, R.M. 1981. The Ordovician proetacean trilobite Rorringtonia. Geological Magazine, 118:89-94.

Owens, R.M. 2002. Cyclopygid trilobites from the Ordovician Builth-Llandrindod Inlier, central Wales. Palaeontology, 45:469-485.

Owens, R.M., Fortey, R.A., Cope, J.C.W., Rushton, A.W.A., and Bassett, M.G. 1982. Tremadoc faunas from the Carmarthen district, South Wales. Geological Magazine, 119:1-112.

Paterson, J.R., Jago, J.B., Brock, G.A., and Gehling, J.G. 2007. Taphonomy and palaeoecology of the emuellid trilobite Balcoracania dailyi (early Cambrian, South Australia). Palaeogeography, Palaeoclimatology, Palaeoecology, 249:302-321.

Peng, J., Babcock, L.E., Zhao, Y., Wang, P., and Yang, R. 2005. Cambrian Sphenothallus from Guizhou Province, China: early sessile predators. Palaeogeography, Palaeoclimatology, Palaeoecology, 220:119-127.

Pratt, B.R. and James, N.P. 1982. Cryptalgal-metazoan bioherms of early Ordovician age in the St George Group, western Newfoundland. Sedimentology, 29:543-569.

Reaka, M.L., Manning, R.B., and Felder, D.L. 1989. The significance of macro- and microhabitat for reproduction in reef-dwelling stomatopods from Belize, p. 183198. In Ferrero, E.A. (ed.): Selected Symposia and Monographs U.Z.I. 3. Mucchi, Modena.

Reich, M. 2001. Ordovician holothurians from the Baltic Sea area, p. 93-96. In Barker, M. (ed.) Echinoderms 2000. Swets and Zeitlinger, Lisse. 
Reich, M. 2010. The oldest synallactid sea cucumber (Echinodermata: Holothuroidea: Aspidochirotida). Paläontologische Zeitschrift, 84:541-546.

Rigby, J.K. and Harris, D.R. 1979. A new Silurian sponge fauna from northern British Columbia, Canada. Journal of Paleontology, 53:968-980.

Rigby, J.K., Maher, B.J., and Browne, Q.J. 1991. New hexactinellids from the Siluro-Devonian of the Snake Mountains, Elko County, Nevada, and a new locality for Gabelia. Journal of Paleontology, 65:709-714.

Servais, T., Owen, A.W., Harper, D.A.T, Kröger, B., and Munnecke, A. 2010. The Great Ordovician Biodiversification Event (GOBE): the palaeoecological dimension. Palaeogeography, Palaeoclimatology, Palaeoecology, 294:99-119.

Shackleton, J.D. 2005. Skeletal homologies, phylogeny and classification of the earliest asterozoan echinoderms. Journal of Systematic Palaeontology, 3:29114.

Sheldon, P.R. 1987a: Parallel gradualistic evolution of Ordovician trilobites. Nature, 330:561-563.

Sheldon, P.R. 1987b. Trilobite evolution and faunal distribution in some Ordovician rocks of the Builth Inlier, Central Wales. Unpublished PhD Thesis, University of Cambridge.

Sheldon, P.R. 1988. Trilobite size-frequency distributions, recognition of instars, and phyletic size changes. Lethaia, 21:293-306.

Smith, A.B. 1988a. Fossil evidence for the relationships of extant echinoderm classes and their times of divergence, p. 85-97. In Paul, C.R.C. and Smith, A.B. (eds.) Echinoderm phylogeny and evolutionary biology. Clarendon Press, Oxford.

Smith, A.B. 1988b. Patterns of diversification and extinction in early Palaeozoic echinoderms. Palaeontology, 31:799-828.

Smith, A.B. and Savill, J.J. 2001. Bromidechinus, a new Ordovician echinozoan (Echinodermata) and its bearing on the early history of echinoids. Transactions of the Royal Society of Edinburgh, Earth Sciences, 92:137-147.

Springer, D.A. and Bambach, R.K. 1985. Gradient versus cluster analysis of fossil assemblages: a comparison from the Ordovician of southwestern Virginia. Lethaia, 18:181-198.

Titus, R. and Cameron, B. 1976. Fossil communities of the lower Trenton Group (Middle Ordovician) of central and northwestern New York State. Journal of Paleontology 50:1209-1225.

Tomašovych, A. and Rothfus, T.A. 2005. Differential taphonomy of modern brachiopods (San Juan Islands, Washington State): effect of intrinsic factors on damage and community-level abundance. Lethaia, 38:271-292.

Topper, T.P., Brock, G.A., Skovsted, C.B., and Paterson, J.R. 2010. Palaeoscolecid scleritome fragments with Hadimopanella plates from the early Cambrian of South Australia. Geological Magazine, 147:86-97.
Van Roy, P., Orr, P.J., Botting, J.P., Muir, L.A., Vinther, J., Lefebvre, B., El Hariri, K., and Briggs, D.E.G. 2010. Ordovician faunas of Burgess Shale type. Nature, 465:215-218

Vincent, T.L.S., Scheel, D., and Hough, K.R. 1998. Some aspects of diet and foraging behaviour of Octopus dofleini (Wülker, 1910) in its northernmost range. Marine Ecology, 19:13-29.

Waisfeld, B.G. and Sánchez, T.M. 1996. "Fauna cámbrica" versus "fauna paleozoica" en el Ordovícico temprano del Oeste de Argentina: interacción entre provincialismo y ambiente. ["Cambrian fauna" versus "Palaeozoic fauna" in the Lower Ordovician of Western Argentina: provincialism and environment interactions]. Geobios, 29:401-416.

Walker, K.R. 1972. Community ecology of the Middle Ordovician Black River Group of New York State. Geological Society of America Bulletin, 83:24992523.

Webby, B.D., Droser, M.L., Paris, F., and Percival, I.G. (eds.) 2004. The Great Ordovician Biodiversification Event. Columbia University Press, New York.

Whittard, W.F. 1953. Palaeoscolex piscatorum gen. et sp. nov., a worm from the Tremadocian of Shropshire. Quarterly Journal of the Geological Society, London, 109:125-135.

Wiedman, L.A. 1985. Community palaeoecology study of the Silica Shale equivalent of northeastern Indiana. Journal of Paleontology, 59:160-182.

Wilby, P.R., Wilkinson, I.P., and Riley, N.J. 2005. Late Carboniferous scavenging ostracodes: feeding strategies and taphonomy. Earth and Environmental Science Transactions of the Royal Society of Edinburgh, 96:309-316.

Wilcox, C.J. and Lockley, M.G. 1981. A reassessment of facies and faunas in the type Llandeilo (Ordovician), Wales. Palaeogeography, Palaeoclimatology, Palaeoecology, 34:285-314.

Williams, A., Lockley, M.G., and Hurst, J.M. 1981. Benthic palaeocommunities represented in the Ffairfach Group and coeval Ordovician successions of Wales. Palaeontology, 24:661-694.

Worland, M.R., Leinaas, H.P., and Chown, S.L. 2006. Supercooling point frequency distributions in Collembola are affected by moulting. Functional Ecology, 20:323-329.

Young, G.A., Rudkin, D.M., Dobrzanski, E.P., Robson, S.P., and Nowlan, G.S. 2007. Exceptionally preserved Late Ordovician biotas from Manitoba, Canada. Geology, 35:883-886.

Zangerl, R.B.G., Woodland, B.G., Richardson, E.S., and Zachry, D.L. 1969. Early diagenetic phenomena in the Fayetteville Black Shale (Mississippian) in Arkansas. Sedimentary Geology, 3:87-120.

Zhang, Z., Holmer, L.E., Robson, S.P., Hu, S., Wang, X., and Wang, H. 2011. First record of repaired durophagous shell damages in Early Cambrian brachiopods with preserved pedicles. Palaeogeography, Palaeoclimatology, Palaeoecology, 302:206-212. 


\section{BOTTING AND MUIR: WELSH HOLOTHURIAN BED}

Ziegler, A.M., Cocks, L.R.M., and Bambach, R.K. 1968. The composition and structure of Lower Silurian marine communities. Lethaia, 1:1-27. 